\title{
Mantle melting and magmatic processes under La Picada stratovolcano (CSVZ, Chile)
}

\author{
Jacqueline Vander Auwera $^{1 *}$, Olivier Namur ${ }^{1-3}$, Adeline Dutrieux ${ }^{1,4}$, Camilla \\ Maya Wilkinson $^{5}$, Morgan Ganerod ${ }^{5}$, Valentin Coumont ${ }^{1}$, Olivier Bolle ${ }^{1}$ \\ ${ }^{1}$ Université de Liège, Département de géologie, B-4000 Liège (Belgium), olivier.bolle@uliege.be \\ ${ }^{2}$ Leibniz Universität Hannover, Institute of Mineralogy, D-30167 Hannover (Germany) \\ ${ }^{3}$ University of Leuven, Department of Earth and Environmental Sciences, B-3001 Leuven (Belgium), \\ olivier.namur@kuleuven.be \\ ${ }^{4}$ University of Southampton, Ocean and Earth Science, Southampton S017 1BJ (UK) \\ (A.Dutrieux@noc.soton.ac.uk) \\ ${ }^{5}$ Geological Survey of Norway, NO-7491 Trondheim (Norway) (morgan.ganerod@,ngu.no) \\ *Corresponding author. Telephone: +32 4366 2253. Fax: +32 4366 2921. E-mail: jvdauwera@uliege.be
}

\section{ABSTRACT}

Where and how arc magmas are generated and differentiated are still debated and these questions are investigated in part of the Andean arc (Chilean Southern Volcanic Zone) where the continental crust is thin. Results are presented for the La Picada stratovolcano $\left(41^{\circ} \mathrm{S}\right)$ that belongs to the Central Southern Volcanic Zone (CSVZ) $\left(38^{\circ} \mathrm{S}-41.5^{\circ} \mathrm{S}\right.$, Chile) which results from the subduction of the Nazca plate beneath the western margin of the South American continent. Forty-seven representative samples collected in different units of the volcano define a differentiation trend from basalt to basaltic andesite and dacite (50.9 to $\left.65.6 \mathrm{wt} . \% \mathrm{SiO}_{2}\right)$. This trend straddles the tholeiitic and calc-alkaline fields and displays a conspicuous compositional (Daly) gap between 57.0 and 62.7 wt. \% $\mathrm{SiO}_{2}$. Interstitial, mostly dacitic glass pockets extend the trend to 76.0 wt. $\% \mathrm{SiO}_{2}$. Mineral compositions and geochemical data indicate that differentiation from the basaltic parent magmas to the dacites occurred in the upper crust $(\sim 0.2 \mathrm{GPa})$ with no sign of an intermediate fractionation stage in the lower crust. However, we have currently no precise constraint on the depth of 
differentiation from the primary magmas to the basaltic parent magmas. Stalling of the basaltic parent magmas in the upper crust could have been controlled by the occurrence of a major crustal discontinuity, by vapor saturation that induced volatile exsolution resulting in an increase of melt viscosity or by both processes acting concomitantly. The observed Daly gap thus results from upper crustal magmatic processes. Samples from both sides of the Daly gap show contrasting textures: basalts and basaltic andesites, found as lavas, are rich in macrocrysts, whereas dacites, only observed in crosscutting dykes, are very poor in macrocrysts. Moreover, modelling of the fractional crystallization process indicate a total fractionation of $43 \%$ to reach the most evolved basaltic andesites. The Daly gap is thus interpreted as resulting from critical cristallinity that was reached in the basaltic andesites within the main storage region, precluding eruption of more evolved lavas. Some interstitial dacitic melt was extracted from the crystal mush and emplaced as dykes possibly connected to small dacitic domes, now eroded away. In addition to the overall differentiation trend, the basalts to basaltic andesites display variable $\mathrm{MgO}, \mathrm{Cr}$ and $\mathrm{Ni}$ contents at a given $\mathrm{SiO}_{2}$. Crystal accumulation and high pressure fractionation fail to predict this geochemical variability which is interpreted as resulting from variable extent of fractional crystallization. Geothermobarometry using recalculated primary magmas indicates last equilibration at about 1.3-1.5 GPa and at a temperature higher than the anhydrous peridotite solidus pointing to a potential role of decompression melting. However, because the basalts are enriched in slab components and $\mathrm{H}_{2} \mathrm{O}$ compared to N-MORBs, wet melting is highly likely.

KEYWORDS: Arc magmatism; Chilean Southern Volcanic Zone; Daly gap; Magma differentiation; Primary magmas 


\section{INTRODUCTION}

The depth and detailed mechanisms of arc magma generation and differentiation are long standing debates that are crucial to the Earth Sciences as, at least since the Proterozoic, the continental crust is mainly built at subduction zones. The thickness of the crust seems to play a determining role. It influences the thermal structure of the mantle wedge and thus the compositional variability of primary arc magmas (Chin et al., 2018; Plank \& Langmuir, 1988; Turner et al., 2016; Turner \& Langmuir, 2015a; Turner \& Langmuir, 2015b). It also controls magmatic differentiation processes and according to (Farner \& Lee, 2017) average arc magmas are more evolved, enriched in incompatible elements and more oxidized when the crust is thick. Finally, it determines the depth of magma differentiation and a thicker continental crust appears to promote deep crustal differentiation. It is currently acknowledged that during their transit through the crust, magmas are probably stalled and stored at various depths within protracted or transient reservoirs. Yet constraining the location of prolonged storage sites is challenging. The recognition that the crust/mantle boundary could act as a density filter and induce the stalling of basaltic magmas has prompted several authors to favor deep fractionation (e.g. Annen et al., 2015; Annen et al., 2006), a process that is indeed supported by the occurrence of lower crustal mafic and ultramafic cumulates in some arc sections (e.g. Searle et al., 1999). However, petrological and geochemical arguments question this model and point to the shallow crust as the main site of differentiation (e.g. Adam et al., 2016; Turner \& Langmuir, 2015a). A striking characteristic of arc magmas is the abundance of andesitic rocks (e.g. Wörner et al., 2018) and the relative paucity of true andesitic liquids (Daly gap) 
(e.g. Reubi \& Blundy, 2009) compared to the mafic and silicic endmembers. Several processes that have been proposed to take into account this compositional bimodality take place in the lower crust (Melekhova et al., 2013; Reubi \& Blundy, 2009) and accordingly, andesitic rocks are interpreted as resulting from mingling/mixing between the two endmembers in shallow magmatic reservoirs. Lower crustal differentiation would thus be essential in producing the Daly gap.

In this paper, we focus on the central part of the Chilean Southern Volcanic Zone (SVZ) where the geochemical trends of several volcanoes, including La Picada and Osorno (Fig. 1), display a compositional (Daly) gap between dominant basaltic andesites and minor dacites. In this part of the Andean arc, the continental crust is thin $(\approx 30 \mathrm{~km})$ and its permeability is enhanced by a major regional structure, the LiquiñeOfqui Fault Zone, that likely facilitates magma ascent (Hickey-Vargas et al., 2016a) (Fig. 1) suggesting that most of the differentiation could have taken place in the upper crust. The SVZ has been the subject of numerous studies that have mostly emphasized along arc regional trends in the eruptive products (Lopez-Escobar, 1984) correlating with geochemical trends (Deruelle et al., 1983; Hickey et al., 1984; Hickey et al., 1986; Hickey-Vargas et al., 2016a; Hildreth \& Moorbath, 1988; Jacques et al., 2013; Lopez-Escobar, 1984; Morris et al., 1990; Sigmarsson et al., 2002; Stern et al., 1984; Tormey et al., 1991) and were focused on the potential sources of the magmas. Specific volcanoes of the SVZ have also been investigated (e.g. Bouvet De Maisonneuve et al., 2013; Hickey-Vargas et al., 2016b; Higgins et al., 2015; Kratzmann et al., 2010; Lopez-Escobar et al., 1995; Lopez-Escobar et al., 1981; Reubi et al., 2011; Ruprecht et al., 2012; Ruth et al., 2016). However, despite this abundant research, few detailed petrological studies (e.g. Ruprecht et al., 2012; Watt et al., 2013) that take into account the whole life cycle of a volcano and constrain the 
sites and conditions of mantle melting and magma differentiation, have been undertaken in this part of the arc. In this study, our aims are thus (1) to provide new detailed geochemical and mineralogical data, as well as new ${ }^{40} \mathrm{Ar}-{ }^{39} \mathrm{Ar}$ (hereafter $\mathrm{Ar}-$ Ar) ages on a collection of samples from La Picada, (2) to constrain the magma storage conditions and processes of magma differentiation under La Picada and (3) to place additional constraints on mantle melting in this part of the arc.

\section{THE SOUTHERN VOLCANIC ZONE OF THE ANDEAN ARC AND LA PICADA VOLCANO}

The Andean arc results from the subduction of the Cocos, Nazca and Antartica plates under the South American plate. It has been subdivided in several volcanic zones, namely the North $\left(10^{\circ} \mathrm{N}-5^{\circ} \mathrm{S}\right)$, Central $\left(5^{\circ} \mathrm{S}-33.5^{\circ} \mathrm{S}\right)$, Southern $\left(33.5^{\circ} \mathrm{S}-46.5^{\circ} \mathrm{S}\right)$ and Austral $\left(46.5^{\circ} \mathrm{S}-56^{\circ} \mathrm{S}\right)$ zones, separated by volcanic gaps (Fig. 1a inset) (Stern, 2004). In the Chilean Andes, the Southern Volcanic Zone (SVZ) stretches from $33.5^{\circ}$ to $46.5^{\circ} \mathrm{S}$, its northern and southern limits corresponding to subduction of respectively, the Juan Fernández Ridge and the Chile Rise that separates the Nazca and Antartica plates (Stern, 2004) (Fig. 1a). The SVZ has itself been subdivided into northern (NSVZ: $\left.33^{\circ} \mathrm{S}-34.5^{\circ} \mathrm{S}\right)$, transitional (TSVZ: $\left.34.5^{\circ} \mathrm{S}-37^{\circ} \mathrm{S}\right)$, central (CSVZ: $37^{\circ} \mathrm{S}-$ $\left.41.5^{\circ} \mathrm{S}\right)$ and southern (SSVZ: $\left.41.5^{\circ} \mathrm{S}-46^{\circ} \mathrm{S}\right)$ zones by (Lopez-Escobar \& Moreno, 1994; Lopez-Escobar et al., 1995). Recently, Hickey-Vargas et al. (2016b) proposed to move the northern limit of the $\mathrm{CSVZ}$ from $37^{\circ} \mathrm{S}$ to $38^{\circ} \mathrm{S}$, this new limit corresponding to the northern extremitity of an important intra-arc, transpressional dextral strike-slip structure, the $1200 \mathrm{~km}$-long Liquiñe-Ofqui fault zone (LOFZ) extending from $38^{\circ}$ to $47^{\circ} \mathrm{S}$ (Cembrano et al., 1996), to which the SSVZ is related 
(Fig. 1a). At $38^{\circ} \mathrm{S}$, the composition of the basement is also changing from MesoCenozoic volcano-sedimentary rocks in the north to the Meso-Cenozoic plutonic rocks of the Patagonian Batholith in the south (Cembrano \& Lara, 2009). The convergence between the Nazca plate and South America is slightly oblique to the trench direction $\left(\sim 26^{\circ}\right.$ at $40^{\circ} \mathrm{S}$ : Jarrard, 1986) and occurs at a rate of $66 \mathrm{~mm} / \mathrm{y}$ (Angermann et al., 1999). At Osorno (41.1º $\mathrm{S}$ ), the normal component of plate convergence rate is $72.1 \mathrm{~mm} / \mathrm{y}$ (Syracuse \& Abers, 2006). In the SVZ, the thickness of the continental crust under the arc, depth of the MOHO, varies from $50 \mathrm{~km}$ in the north to about $30 \mathrm{~km}$ in the south (Assumpção et al., 2013; Hickey-Vargas et al., $2016 \mathrm{~b}$ ), with a value of $32 \mathrm{~km}$ at a latitude of $39.5^{\circ} \mathrm{S}$ (Syracuse et al., 2010). According to Syracuse \& Abers (2006), at Osorno, the volcano-slab distance is 72 $\mathrm{km}$, the volcano-trench distance perpendicular to the slab strike is $220 \mathrm{~km}$ and the average dip of the slab is $39^{\circ}$.

La Picada together with Osorno, Puntiagudo and Cordón Cenizos define a small chain that is oriented at $\mathrm{N} 45^{\circ} \mathrm{E}$, oblique to the main volcanic arc (Fig. 1a-c). Available K-Ar and Ar-Ar ages indicate that the history of this oblique chain started at about $500 \mathrm{ky}$ ago, before the onset of Osorno at $300 \mathrm{ky}$, and lasted until $60 \mathrm{ky}$ corresponding to the ultimate building phase of Osorno (Moreno et al., 2010). La Picada is located at about $6 \mathrm{~km}$ to the north-east of the Osorno volcano summit. It is older than Osorno and thus recorded the early activity of the Osorno-PuntiagudoCordón Cenizos chain. It has not erupted in historical time, whereas Osorno last erupted in 1830. La Picada is now extinct, but its geochemistry and close proximity with Osorno indicate possible interaction of the plumbing systems of the two volcanoes during the early stages of Osorno (Biggs et al., 2016; Moreno et al., 2010). It has been deeply eroded by the Santa Maria and Llanquihue glaciations (58000 to 
14200 y BP : Porter, 1981). The flanks of La Picada expose a series of intercalated 5

to $15 \mathrm{~m}$ thick units made of basaltic lavas and breccias, that are cut by numerous subvertical dykes (Moreno et al., 2010). These dykes are well exposed on the southern flank of La Picada that faces Osorno. It will be shown that these dykes are mostly dacitic and were probably located below small dacitic domes, now eroded away, similar to the two domes that have been mapped on the southern and western flanks of Osorno (Moreno et al., 2010). At least two generations of dykes have been observed on the southern flank as illustrated on Figure 2, where an inner dyke, referred to as dyke 2, displays conspicuous chilled margins at the contact with an outer dyke, called dyke 1, indicating that dyke 2 was emplaced after dyke 1, within the same weakness zone (dyke-in-dyke intrusion). Dark black pyroclastic deposits are rather abundant in some parts of La Picada and were most probably emplaced during the last eruption of Osorno. They were thus not considered in this study. Blocks of gabbroic rocks are frequent and are interpreted as fragments from the plutonic basement.

\section{SAMPLE COLLECTION}

Samples were collected during three field seasons $(2013,2014,2015)$ that focused on the La Picada, Osorno and Calbuco volcanoes. La Picada samples comprise thirty lavas, thirteen samples from the dykes as well as four samples of gabbroic fragments, hence a total of fourty-seven. Samples PIC39, 40, 47 and 48 were collected in dykes 2 whereas samples PIC38, 42 and 49 are from dykes 1. Sample PIC41 was collected just at the contact between the inner and outer dykes and was initially considered as part of dykes 1 but its trace elements content clearly indicate that it belongs to dykes 2 
(see below). PIC51 and 52 were sampled in a non-composite dyke and grouped with dykes 1. Samples PIC05, 06, 30, 31, 34 and 35 are from homogeneous blocks of the breccias. The location of each sample (latitude, longitude) is reported in Table 1.

\section{CRYSTAL TERMINOLOGY}

Detailed observations, geochemical data and quantification of crystal textures in volcanic rocks have revealed the occurrence of multiple crystal populations (e.g. Davidson et al., 2007). This has prompted the use of several terms (phenocrysts, xenocrysts, antecrysts and microlites) that are genetic (e.g. Jerram \& Martin, 2008). More particularly, the term phenocryst has evolved from a descriptive meaning, large crystals in a finer grained matrix, to a genetic one as for many petrologists it designates a crystal in equilibrium with the magma (e.g. Jerram \& Martin, 2008). Here, we will follow the terminology recently adopted by several authors (e.g. Neave et al., 2014) and use the non-genetic terms macrocrysts and microlites to refer to crystals with a long axis length respectively larger and smaller than 150 microns. The prefix « macro » does not mean that the crystals are significantly large as in the La Picada lavas macrocrysts have a maximum long axis of $2 \mathrm{~mm}$.

\section{ANALYTICAL METHODS}

\section{Ar-Ar ages}

Six samples were dated using the Ar-Ar method to complement existing data (Moreno et al., 2010): basalts PIC04 and PIC06 as well as basaltic andesites PIC07, PIC09, 
PIC11 and PIC12. Fragments of the bulk rocks were crushed and the coarse grain fraction $(0.5-1 \mathrm{~mm})$ was retained while finer fractions were discarded. The groundmass was separated from macrocrysts (e.g. altered grains, glass, olivine and pyroxene macrocrysts) under a binocular microscope, and washed in a solution of 5\% $\mathrm{HNO}_{3}$ to remove alteration products before repeated rinses with de-ionized water to remove traces of $\mathrm{HNO}_{3}$. Approximately, $500 \mathrm{mg}$ of clean matrix was wrapped in aluminium foil and irradiated in the nuclear reactor at the Institutt for the Energiteknikk (Kjeller, Norway) for 4 hours with an integrated flux of $1.32 \times 10^{13}$ neutrons $/ \mathrm{cm}^{2}$.s. The sanidine from Alder Creek (ACS) having an age of $1.206 \pm 0.002$ Ma (Renne et al., 2010) was selected as a monitor mineral to constrain and interpolate the irradiation parameters essential in the radiometric dating equation. For irradiation each sample was bracketed by two aliquots of the monitor mineral. Samples and standards were loaded in an aluminium holder and placed in an ultrahigh vacuum extraction line. Samples and standards were degassed incrementally using a $\mathrm{CO}_{2}$ laser probe $(\lambda=10600 \mathrm{~nm})$ and the gas analyzed isotopically using a MAP215-50 noble gas mass spectrometer (Geological Survey of Norway (NGU), Trondheim). Due to the anticipated young age and potassium-poor nature of the samples, cautious monitoring of the mass discrimination of the mass spectrometer (via calibration air shots measurement prior to each sample), and volume reduction of the extraction line system were carried out in order to measure the small volume of radiogenic Ar. Corrections for irradiation induced excess Ar from calcium and potassium interferences were applied. Correction factors, irradiation parameters, number of incremental heating steps and age results are shown in Table 2.

\section{Mineral chemistry}


The major elemental composition of minerals and glasses of the La Picada samples was measured with a CAMECA SX100 electron microprobe at the University of Hannover with an accelerating voltage of $15 \mathrm{kV}$. Mineral analyses were performed with a focused beam $(1 \mu \quad)$ and a beam current of $5 \mathrm{nA}$. Each element was measured $15-20 \mathrm{~s}$. For the glass analyses, the beam current was set at $8 \mathrm{nA}$ and the beam was defocused to $5 \mu$. The following standards were used: albite for $\mathrm{Na}$, orthoclase for $\mathrm{K}$, wollastonite for $\mathrm{Si}$ and $\mathrm{Ca}, \mathrm{TiO}_{2}$ for $\mathrm{Ti}, \mathrm{Fe}_{2} \mathrm{O}_{3}$ for $\mathrm{Fe}, \mathrm{MgO}$ for $\mathrm{Mg}, \mathrm{Mn}_{3} \mathrm{O}_{4}$ for $\mathrm{Mn}$. Raw data were corrected with the CATZAF program. In order to detect the possible occurrence of different crystal populations, profiles across grains or from rims to cores were realized in olivine ( 873 analyses: Table S1, supplementary data are available for downloading at http://www.petrology.oxfordjournals.org), plagioclase (2904 analyses: Table S2), orthopyroxene (258 analyses: Table S3) and clinopyroxenes (607 analyses: Table S3) in a series of samples (PIC01, 02, 03, 04, 06, $07,08,10,12,19,24,30,31,33,34,35,36,37,41,43,44,48,50)$ representative of the different facies of the volcano. Titanomagnetite was also analysed in 10 samples (PIC02, 12, 14, 15, 24, 32, 33, 38, 48, 50: Table S4) together with ilmenite (PIC02, $03,12,15,24,32$ : Table S4) that occurs as small exolution lamellae in Ti-magnetite whereas chromite inclusions were analysed in the olivine of sample PIC50. Glass composition (Table S5) was measured in a few basalts (PIC31, 50), basaltic andesites (PIC07, 10, 14) and dacites (PIC39, 41). In the basalts and basaltic andesites, glass occurs in very small interstitial pockets that locally contain microlites of Fe-Ti oxides and possibly plagioclase. Contrarily, the dacites are poor in macrocrysts enabling analyses of microlite-free glass. 


\section{Whole-rock chemistry}

Forty-seven samples were crushed with a hammer and then ground in agate mortar with a Fritsch pulverisette planetary mill. Major elements were measured by X-ray fluorescence at the University of Liège. An ARL 9400 XP spectrometer was used for samples PIC01 to PIC13 and a Thermofisher PERFORM'X for the rest of the samples. Both spectrometers were equipped with a Rh tube. The major elements were measured on fused glass discs that were prepared with $0.35 \mathrm{~g}$ of rock powder, previously dried at $1000^{\circ} \mathrm{C}$ for two hours in the oven, and lithium- and tetra-borate. Calibration curves were calculated by measuring a series of 47 to 66 international standards that are mostly rock samples (basalts to granites, syenites, ultramafic rocks, sedimentary rocks) but also include a few minerals and two soils. Repeated analyses of external standards, not included in the calibration curves, indicate that the accuracy is better than $\pm 3.5 \%$ for all major elements, except for $\mathrm{TiO}_{2}( \pm 4.9 \%), \mathrm{Na}_{2} \mathrm{O}( \pm 12.4$ $\%)$ and $\mathrm{P}_{2} \mathrm{O}_{5}( \pm 10.3 \%)$. The $1 \sigma$ analytical precision is better than $1 \%$ for all major elements, except for $\mathrm{Na}_{2} \mathrm{O}( \pm 1.3 \%)$ and $\mathrm{P}_{2} \mathrm{O}_{5}( \pm 3.2 \%)$. A Thermo Scientific X-Series 2 ICP-MS (MRAC Tervuren, Belgium) equipped with a collision cell was used to analyse trace elements in samples that were put into solution by alkali fusion. Calibration was performed with international standards prepared in the same way as rock samples, as well as with standard solutions prepared with element solutions. Accuracy and precision were estimated by repeated analyses of 12 standards and range between 2.0 and $5.7 \%$ and between 1.5 and $5.2 \%$, respectively (one sigma) (Navez, 1995). Results are shown in Table 1.

\section{Point counting}


The proportions of macrocrysts, vesicules and matrix have been determined by point counting with a PELCON Automatic Point Counter in 12 samples ranging from basalt to basaltic andesite. Steps of $0.5 \mathrm{~mm}$ have been used along the $\mathrm{x}$ - and $\mathrm{y}$-axes giving about 1500 points per sample. Vesicles, macrocrysts of plagioclase, olivine, orthopyroxene, clinopyroxene and Ti-magnetite were counted. Crystals smaller than 100 microns were considered as groundmass. The mass proportions of crystals on a vesicle-free basis were obtained by considering the following densities: $2.7 \mathrm{~g} / \mathrm{cm}^{3}$ for plagioclase and groundmass, $3.3 \mathrm{~g} / \mathrm{cm}^{3}$ for olivine, $3.2 \mathrm{~g} / \mathrm{cm}^{3}$ for pyroxenes and 5.0 $\mathrm{g} / \mathrm{cm}^{3}$ for Ti-magnetite. Variation of density due to the compositional evolution of the solid solutions influences the calculated mass proportions but the error on the reproducibility of the point counting is much higher (Table 3) and constant densities have thus been considered. The proportion of macrocrysts ranges from $28.7 \%$ to $54.4 \%$. Plagioclase displays the highest proportion within the macrocrysts, from $68 \%$ to $99 \%$.

\section{PETROGRAPHY, MINERAL CHEMISTRY AND PHASE PROPORTIONS}

La Picada samples range from basalts (PIC04, 5, 6, 30, 31, 37, 43, 50) to dacites $(38$, 39, 40, 41, 42, 47, 48, 49, 51, 52), basaltic andesites being dominant (PIC01, 2, 3, 7, $8,9,10,12,13,14,15,18,19,21,24,32,33,34,35,36,44)$ and andesites conspicuously absent (see TAS diagram on Fig. 3). The dacites were all collected in the dykes crosscutting the southern flank. The textures are mostly microlitic porphyric, hyalopilitic or trachytic. All samples contain macrocrysts of plagioclase except PIC04 where olivine is the sole macrocryst (Fig. 4a). 
Basalts and basaltic andesites are variably vesicular (up to $40 \%$ ) and display changing proportions (18 to $54 \mathrm{vol} \%$ ) of plagioclase, olivine and pyroxenes macrocrysts dispersed in a groundmass that is usually microcrystalline. Glomerocrysts are nearly ubiquitous and are dominated by plagioclase grains showing either a shapepreferred or a random orientation. Plagioclase, up to $2 \mathrm{~mm}$ long and $600 \mu \mathrm{m}$ large, ranges in composition from $\mathrm{An}_{92}$ (basalts)/ $\mathrm{An}_{93}$ (basaltic andesites) in the cores to $\mathrm{An}_{39}$ (basalts)/ $\mathrm{An}_{28}$ (basaltic andesites) in the rims. Compositional histograms display corresponding peaks at about $\mathrm{An}_{85}$ (basalts)/An82-90 (basaltic andesites) and $\mathrm{An}_{65}$ (basalts)/An60 (basaltic andesites) (Fig. 5a). Typical core-rim compositional profiles display a core surrounded by a zone of decreasing anorthite content followed by a rim that usually has a constant composition (Fig. 6). Plagioclase shows a large range of textures depending on the amount and location of inclusions in the grains (Fig. 4b). Partly to totally recrystallized melt inclusions may be present throughout the crystal or concentrated in concentric zones or in the core. The mineralogy of the ferromagnesian macrocrysts varies with the whole rock composition. In the basalts (up to $52.50 \%$ $\mathrm{SiO}_{2}$, PIC 35), olivine (Fo86-65, Fig. 5a), up to 2mm-long and $1.5 \mathrm{~mm}$-large, is the dominant ferromagnesian and is accompanied by some augite $(\mathrm{Mg} \#=71.6-57.7$ : Fig. 5a-b), up to $700-\mu \mathrm{m}$ long and $400-\mu \mathrm{m}$ large. Augite is locally surrounded by pigeonite that also occurs in the groundmass. Olivine is usually idiomorphic and contains small inclusions of dark brown chromite in several basaltic samples (PIC04, 06, 50). Titanomagnetite has not been observed as macrocrysts in the basalts but is abundant as microlites $\left(\mathrm{Uvsp}_{63}\right)$. In the basaltic andesites (from $52.52 \%$ to $56.35 \% \mathrm{SiO}_{2}$ ), olivine (Fo80-51: Fig. 5a) is accompanied by orthopyroxene $(\mathrm{Mg} \#=74.2-59.2$ : Fig. 5ab) and augite $(\mathrm{Mg} \#=82.8-64.7$ : Fig. 5a-b). Here too, augite is locally surrounded by pigeonite also occurring as microlites in the groundmass. Olivine usually occurs as 
isolated grains displaying varying transformation into iddingsite that grew preferentially from the rim of the grains and along microfractures. A thin rim of opaque grains surrounding olivine is nearly ubiquitous. Orthopyroxene and clinopyroxene also occur as idiomorphic grains. Locally orthopyroxene is surrounded by a rim of pigeonite. In about half of the basaltic andesites, titanomagnetite, locally displaying exsolution lamellae of ilmenite, occurs as microlites ranging from 50 to $100 \mu \mathrm{m}$. In several glomerocrysts, crystals of olivine are surrounded by corona of orthopyroxene grains suggestive of a peritectical reaction between olivine and the liquid (Fig. 4c).

Contrary to basalts and basaltic andesites, dacites display few plagioclase, pyroxenes and titanomagnetite macrocrysts dispersed in a crypto- to microcrystalline groundmass where some microlites of plagioclase usually define a trachytic texture (Fig. 4d). Plagioclase (An 46 to $\mathrm{An}_{68}$ ) has usually a high aspect ratio, up to $1.5 \mathrm{~mm}$ long and 500- $\mu \mathrm{m}$ large, but more equant grains are locally observed. In striking contrast with what is seen in the basalts and basaltic andesites, plagioclase has few to no inclusions and display less complex zoning patterns (Fig. 4d). Olivine is absent, whereas idiomorphic orthopyroxene $(\mathrm{Mg} \#=63.0$ : Fig. 5a-b), up to $1 \mathrm{~mm}-$ long and $250-\mu \mathrm{m}$ large, together with augite $(\mathrm{Mg} \#=72.2-60.3$ : Fig. 5a-b), up to 500- $\mu \mathrm{m}$ long and $250-\mu \mathrm{m}$ large, occur in nearly equal abundances. Augite is frequently twinned and equant grains of titanomagnetite are larger, about $125 \mu \mathrm{m}$, than in the basaltic andesites.

Amphibole is lacking in the whole series of La Picada samples. The petrographic observations suggest that olivine appears first on the liquidus either together with plagioclase or shortly followed by it. After some differentiation, 
clinopyroxene crystallizes and olivine reacts into orthopyroxene. Titanomagnetite is a late phase.

Rhodes diagrams (Fig. 7) show that the cores of olivine in the basalts and basaltic andesites $\left(K_{D}^{F e-M g}=0.30 \pm 0.03\right.$ : Roeder \& Emslie, 1970 $)$ and of augite in the basaltic andesites $\left(K_{D}^{F e-M g}=0.27 \pm 0.03\right.$ : Putirka, 2008) are in equilibrium with the whole rock. The $K_{D}^{F e-M g}$ proposed by Putirka (2008) for clinopyroxene-melt equilibria is appropriate here as experimental data performed on starting compositions similar to the parent magmas of La Picada and with variable $\mathrm{H}_{2} \mathrm{O}$ contents $(0$ to 8.98 wt. \%)(Andújar et al., 2015; Blatter et al., 2013; Draper \& Johnston, 1992) give an average $K_{D}^{F e-M g}=0.26 \pm 0.04$. In the dacites, the clinopyroxene macrocrysts are scarce and of small size (up to $500 \mu \mathrm{m})$. Available data indicate that their $\mathrm{Mg} \#(0.68$ to 0.72$)$ is generally too high to be in equilibrium with the $\mathrm{WR}(\mathrm{Mg} \#=0.60)$ but is appropriate for clinopyroxenes in equilibrium with the most evolved basaltic andesite (Fig. 7). However, three analyses performed in the rims of clinopyroxenes from sample PIC48 have a lower $\mathrm{Mg} \#(0.60$ to 0.62$)$ that is in equilibrium with the whole rock (Fig. 5b, Table S3). An equilibrium test was not performed for plagioclase because the composition of this mineral depends on several parameters (magma composition, temperature, pressure and $\mathrm{H}_{2} \mathrm{O}$ content; e.g. Waters \& Lange, 2015). We however note An rich plagioclase cores $\left(\mathrm{An}_{93}\right)$ in the basaltic andesites suggesting equilibrium with the whole rock (see thermobarometry section in the following). Moreover, plagioclase rims from the basaltic andesites have overlapping composition with plagioclase from the dacites (Fig. 5a). As it will be shown below that the dacitic composition (dykes 1) can be produced by fractional crystallization from the basalts and basaltic andesites, we interpret the normal zoning of the plagioclase as resulting from differentiation of the interstitial melt in a crystal mush, the plagioclase rims 
being in equilibrium with a more evolved composition than the bulk rock. Analogy can be made here with what is observed in layered intrusions such as the Skaergaard (e.g. Namur et al., 2014). Mineral data thus suggest that the basalts and basaltic andesites mainly entrained their own crystals, whereas in the dacites, the clinopyroxene may have been captured from the crystal mush and the small plagioclase crystals probably crystallized from the dacitic melt during the ascent.

\section{RESULTS}

\section{Whole-rock and glass chemistry}

\section{Rock classification}

As already noted, whole-rock samples range from basalts to dacites with dominant basaltic andesites (Fig. 3a). The conspicuous absence of andesites results in a compositional (Daly) gap between 56.96\% $\mathrm{SiO}_{2}$ (PIC33) and 62.74\% $\mathrm{SiO}_{2}$ (PIC49), in striking contrast with what is observed in the Central Andes where lavas of andesitic composition are dominant (Wörner et al., 2018). One of the least differentiated basalt samples (PIC 50) has been collected in a dyke (Fig. 3a). The La Picada trend is at the boundary between the tholeiitic and calc-alkaline fields (Irvine \& Baragar, 1971) (Fig. 3b) and at the boundary between the Low-K tholeiites and calc-alkaline fields, except for some dacites that are higher in $\mathrm{K}_{2} \mathrm{O}$ and thus plot in the calc-alkaline field (Peccerillo \& Taylor, 1976) (Fig. 3c). The least differentiated compositions are tholeiitic basalts. Interstitial glass pockets are dacitic in the dacites, but with higher $\mathrm{SiO}_{2}$ than the whole rocks, and dacitic to rhyolitic in the basalts and 
basaltic andesites, with the exception of one andesitic glass analyzed in a basalt. The composition of the glass pockets in the basalts and basaltic andesites is rather scattered, particularly for $\mathrm{FeO}_{\mathrm{t}}, \mathrm{TiO}_{2}$ and $\mathrm{Al}_{2} \mathrm{O}_{3}$. This scatter is probably due to their very small size and to the presence of some microcrystals of oxides and/or plagioclase as the electron microprobe beam was defocused during their analysis. The composition of these glass pockets should be different from the composition of the interstitial liquid of the basaltic to basaltic andesitic crystal mush as most microlites crystallized during final magma ascent to the surface (e.g. Erdmann et al., 2016). We have calculated the composition of such an interstitial melt for sample PIC33 by subtracting the composition of the macrocrysts assemblage from the composition of the bulk rock. In this calculation, we used the proportions of macrocrysts measured by point counting. The composition of the macrocrysts was taken as the average of all analyses of each mineral present in sample PIC33. Sample PIC33 was selected because it is the most evolved basaltic andesite, analyses are available for all macrocrysts and the proportions of macrocrysts were measured three times, the average being used in the calculation. The calculated matrix is andesitic, similar to the andesitic glass pocket analysed in a basalt, and slightly less differentiated than the dacites from the glass pockets and the dykes (Supplementary figure S6).

\section{Major elements}

In Harker diagrams (Fig. 8 and $\mathrm{S} 6$, Table 1), $\mathrm{MgO}, \mathrm{FeO}_{\mathrm{t}}$ and $\mathrm{CaO}$ decrease with increasing $\mathrm{SiO}_{2}$ whereas $\mathrm{K}_{2} \mathrm{O}$ and $\mathrm{P}_{2} \mathrm{O}_{5}$ increase, but only slightly for $\mathrm{P}_{2} \mathrm{O}_{5}$. $\mathrm{TiO}_{2}$ is relatively constant with differentiation, whereas $\mathrm{Al}_{2} \mathrm{O}_{3}$ is first constant and then decreases with increasing $\mathrm{SiO}_{2}$ in the dacites. Contrarily, $\mathrm{Na}_{2} \mathrm{O}$ first increases and 
then remains constant in the dacites. In the $\mathrm{MgO}-\mathrm{SiO}_{2}$ diagram, basalts and basaltic andesites display variable $\mathrm{MgO}$ content for a given value of $\mathrm{SiO}_{2}$. We have thus discriminated these samples as High- $\mathrm{MgO}$ and Low-MgO, as well as Intermediate (Int)- $\mathrm{MgO}^{+}$and Intermediate (Int)- $\mathrm{MgO}^{-}$for $\mathrm{MgO}$ contents plotting between the High- and Low-MgO samples, the Int- $\mathrm{MgO}^{+}$samples having slightly higher $\mathrm{MgO}$ contents than the Int- $\mathrm{MgO}^{-}$samples. Low-MgO samples are also higher in $\mathrm{Al}_{2} \mathrm{O}_{3}$ than the High-MgO samples. These differences are indeed due to variable $\mathrm{MgO}$ contents and not to variable $\mathrm{SiO}_{2}$ contents as they are observed in all major elements variation diagrams when $\mathrm{MgO}$ is used as a differentiation index.

\section{Trace elements}

$\mathrm{Ni}$ and $\mathrm{Cr}$ strongly decrease with increasing $\mathrm{SiO}_{2}$ (Fig. 9, Table 1) and to a lesser extent, Sc, $\mathrm{V}$ and $\mathrm{Co}$ whereas $\mathrm{Zn}$ and $\mathrm{Ga}$ are rather constant (not shown). $\mathrm{Rb}, \mathrm{Ba}, \mathrm{Cs}$ (not shown) and High Field Strength elements (HFSE) (Zr, Hf, Nb, Ta, U, Th, Y, REE) are incompatible, whereas Sr remains first constant but is lower in the dacites. The $\mathrm{Pb}$ data (not shown) display a rather constant trend in the basalts and basaltic andesites and then a strong increase in the dacites. LREE are slightly fractionated with $\mathrm{a}(\mathrm{La} / \mathrm{Yb})_{\mathrm{N}}$ overlapping among the High-MgO to Low-MgO samples and displaying a restricted range from 2.44 in the least differentiated sample (PIC50) to 3.67 in the most evolved dacite (PIC41) (Fig. 10: Table 1). There is a slightly negative-tovirtually absent Eu anomaly in the basalts and basaltic andesites $\left(\left(\mathrm{Eu} / \mathrm{Eu}^{*}\right)_{\mathrm{N}}=0.87\right.$ to 1.06), and a slightly more negative one in the dacites $\left(\left(\mathrm{Eu} / \mathrm{Eu}^{*}\right)_{\mathrm{N}}=0.60\right.$ to 0.85$)$ (Table 3). N-MORB normalized spiderdiagrams (Fig. 10) are typical of arc magmas with strong enrichments in LILE ( $\mathrm{Rb}, \mathrm{Cs}, \mathrm{Ba})$, as well as in Th and $\mathrm{U}$, negative 
anomalies in $\mathrm{Nb}$ and $\mathrm{Ta}$ that display similar contents as $\mathrm{N}-\mathrm{MORB}$ and positive anomalies in $\mathrm{Pb}$, as well as in $\mathrm{Sr}$ for the basalts and basaltic andesites. We observe differences in the trace element composition of dacitic samples from dykes 1 and 2: compared to the former, the latter are enriched in $\mathrm{Rb}, \mathrm{Ba}, \mathrm{Cs}, \mathrm{Pb}$ and $\mathrm{HFSE}$ (Fig. 9) and display a more pronounced Eu negative anomaly $\left(\mathrm{Eu} / \mathrm{Eu}^{*}=0.60\right.$ to 0.67 , with an average of $0.64 v s .0 .81$ to 0.87 , with an average of 0.84 ) (Fig. 10). These differences cannot be attributed to analytical uncertainties, as they were verified with XRF analyses for a few elements ( $\mathrm{Rb}, \mathrm{Sr}, \mathrm{Y}, \mathrm{Zr}, \mathrm{Zn}, \mathrm{Ni}, \mathrm{Pb})$.

High-, Low- and Int-MgO samples display overlapping trace element compositions, except for $\mathrm{Cr}$ and $\mathrm{Ni}$ that are distinctly higher in the High-MgO samples than in the Low-MgO samples. Samples PIC14 and 15 (Int- $\mathrm{MgO}^{-}$) are conspicuously rich in Sr, Th and U. This observation has been tested by replicating the ICPMS analyses on several aliquots (three for PIC14 and two for PIC15; averages are shown on Fig. 9). The trace element compositions can be compared to the Chile trench sediments data (Lucassen et al., 2010; Plank, 2014) and to the South Atlantic MORB field (Fig. 11). Indeed, according to Husson et al. (2012) who modelled the flow of the South Atlantic mantle under the South American continent, this part of the mantle is convecting westward under the Andes and above the subducting Nazca plate. Moreover, Jacques et al. (2013) showed that the mantle source of the back arc volcanic rocks of the TSVZ has a South Atlantic affinity. In the $\mathrm{Nb} / \mathrm{Yb}$ vs. $\mathrm{Th} / \mathrm{Yb}$ diagram of Pearce \& Peate (1995) (Fig. 11a), the La Picada samples have higher $\mathrm{Th} / \mathrm{Yb}$ ratios than MORBs but lower than the Chile trench sediments. In the $\mathrm{La} / \mathrm{Sm}$ vs. Ba/Th plot of Elliott (2003) (Fig. 11b), they overlap in composition with the South Atlantic MORBs and are stretched towards the field of the Chile trench sediments. They display higher $(\mathrm{Ba} / \mathrm{Nb})_{\mathrm{N}},(\mathrm{La} / \mathrm{Nb})_{\mathrm{N}}$ and $(\mathrm{Sr} / \mathrm{Nb})_{\mathrm{N}}$ ratios than the South Atlantic 
MORBs (Fig. 11c-d) but show no enrichment in the Ba/Th ratio (Fig. 11b). Finally, the La Picada samples and the Chile trench sediments have partly overlapping composition in the $(\mathrm{Nb} / \mathrm{U})_{\mathrm{N}}$ vs. $(\mathrm{Ce} / \mathrm{Pb})_{\mathrm{N}}$ diagram (Fig. 11e). The Low- and High$\mathrm{MgO}$ basalts have overlapping spiderdiagrams particularly for the elements that track the slab components (Th, La, K, Pb, U, Sr) (Fig. 11f) but the High-MgO samples have a slightly higher $(\mathrm{Ba} / \mathrm{Nb})_{\mathrm{N}}$ ratio (Fig. 11c) than the Low-MgO samples and several High-MgO samples have a higher $(\mathrm{Sr} / \mathrm{Nb})_{\mathrm{N}}$ ratio (Fig. 12d) and a lower $(\mathrm{Ce} / \mathrm{Pb})_{\mathrm{N}}$ ratio (Fig. 11e) than the Low-MgO samples. However, when all samples are taken into account, their variable ratios of incompatible elements overlap.

\section{Ar-Ar ages}

PIC04 and PIC06 display, respectively, four and five continuous steps with $100 \%$ of degassed ${ }^{39} \mathrm{Ar}$. The best estimated ages are calculated with a normal isochron giving an age of $218 \pm 60 \mathrm{ky}$ for PIC04 and of $220 \pm 36 \mathrm{ky}$ for PIC06 (Figs 12a and 12b). No plateau ages were obtained for PIC07, PIC09 and PIC12 however good estimated ages were calculated with a normal isochron $(360 \pm 23 \mathrm{ky}$ for PIC07, $546 \pm 88 \mathrm{ky}$ for PIC09 and $152 \pm 14$ ky for PIC12: Figs 12c, 12d and 12e). PIC07 yields a trapped Ar/Ar ratio that does not overlap with the atmospheric composition suggesting contribution from an excess Ar component. No satisfactory plateau age could be obtained for PIC11, a gabbroic block, and the best age estimation is given by the inverse isochron (9.5512 $\pm 0.89 \mathrm{Ma})$. Moreover, the composition of the trapped $\mathrm{Ar} / \mathrm{Ar}$ does not overlap with the atmospheric composition suggesting a significant amount of excess Ar. Reliable age criteria given by McDougall \& Harrison (1999) are not 
always fully met due to the low K content and young age of the samples. Only PIC06 meets all criteria and therefore, other ages must be cautiously considered although they remain meaningfull. These new ages combined with previous results (Moreno et al., 2010) indicate a continuous eruptive history at La Picada from about $546 \mathrm{ky}$ (this study) to $60 \mathrm{ky}$ (Moreno et al., 2010). This activity was overlapping with that of Osorno (198 ky (Moreno et al., 2010) to present) and Calbuco (342 ky (Sellés \& Moreno, 2011) to present), starting, however, significantly earlier. La Picada thus recorded the early magmatic history of the Osorno-Puntiagudo-Cordón Cenizos active volcanic chain. There is no clear correlation between the age of the La Picada samples and their $\mathrm{MgO}$ content (Fig. 8). For example, samples PIC09 and PIC12 which are both Int- $\mathrm{MgO}^{+}$were respectively dated at $546 \pm 88 \mathrm{ky}$ and $152 \pm 14 \mathrm{ky}$, thus covering nearly the whole period of activity at La Picada. The approximate age of 9.55 Ma obtained for the gabbroic fragment (PIC11) confirms that it belongs to the Miocene granitoids forming the basement of the volcanoes in the area (Lambert \& Wyllie, 1972).

\section{Thermobarometry}

A collection of geothermobarometers were used to estimate the depth $(\mathrm{P})$ and the conditions $\left(\mathrm{T}, f \mathrm{O}_{2}, \mathrm{H}_{2} \mathrm{O}\right)$ of differentiation from the basalts to the basaltic andesites and dacites.

The composition of clinopyroxene in equilibrium with the melt is dependent on pressure and can thus be used as a geobarometer, as proposed by Putirka (2008) (equation 32a). An improved version of this geobarometer $(\mathrm{SEE}= \pm 0.14 \mathrm{GPa})$ was recently proposed by Neave \& Putirka (2017) and can be applied to hydrous and 
anhydrous systems when temperature is above $1100^{\circ} \mathrm{C}$ and $\log f \mathrm{O}_{2}$ lower than QFM +1 (see below). We selected clinopyroxene compositions that are in equilibrium with the whole rock: $K_{D}^{F e-M g}=0.27 \pm 0.03$ and $(\mathrm{DiHd})_{\text {predicted }}-(\mathrm{DiHd})_{\text {observed }} \leq|0.05|($ Neave \& Putirka, 2017). This appeared to be true for several basaltic andesites (PIC02, 07, 08, 12 and 44) (Supplementary Table S7). Results indicate an average of $0.19 \pm 0.07$ GPa when considering all analyses, of $0.18 \pm 0.08 \mathrm{GPa}$ for the Int- $\mathrm{MgO}^{+}$samples (PIC12 and 44) and of $0.21 \pm 0.06 \mathrm{GPa}$ for the Int-MgO- samples (PIC02, 07, 08). Standard deviations of our results are given as the errors as the pressure distribution probably reflects the uncertainty of the model (Neave \& Putirka, 2017). These standard deviations are slightly lower that the SEE of 0.14 GPa given by Neave \& Putirka (2017). The frequency distributions (Fig. 13) display overlapping maxima ( 0.18 to $0.26 \mathrm{GPa}$ for the Int $\mathrm{MgO}^{+} ; 0.18$ to $0.28 \mathrm{GPa}$ for the Int $\mathrm{MgO}^{-}$) and except for a few analyses, pressures are below $0.3 \mathrm{GPa}$. Using a density of $2700 \mathrm{~kg} / \mathrm{m}^{3}$ for the upper crust (Tassara et al., 2006), the pressures of $0.18 \pm 0.08$ to $0.28 \pm 0.06 \mathrm{GPa}$ translate into depths of $6.8 \pm 3 \mathrm{~km}$ to $10.6 \pm 2.3 \mathrm{~km}$. Interestingly, this range of depths corresponds to the intracrustal discontinuity separating the upper and lower continental crust in this part of the Andean arc (Tassara \& Echaurren, 2012; Tassara et al., 2006). A low pressure of differentiation is supported by phase equilibria as the basaltic andesites and dacites of La Picada respectively plot close to the $0.2 \mathrm{GPa}$ clinopyroxene saturated olivine-plagioclase and orthopyroxene-plagioclase boundaries of Grove et al. (2003) (Fig. 14). It also agrees with the results of Turner \& Langmuir (2015a) and Adam et al. (2016) and with the pre-eruptive conditions (0.2 $\mathrm{GPa}$ ) experimentally constrained for the dacite of the San Pedro volcano (36 ${ }^{\circ} \mathrm{SVZ}$ ) (Costa et al., 2004). We thus conclude that differentiation from the basalts to the basaltic andesites and dacites dominantly took place in the upper crust. 
Following the procedure proposed by Mandler et al. (2014), we first estimated the temperature and the $\mathrm{H}_{2} \mathrm{O}$ content of the magma by combining empirical thermometers that are either independent or dependent on the $\mathrm{H}_{2} \mathrm{O}$ content of the melt (Putirka, 2008). The former only depend on the melt composition (equations 13 and 16 from Putirka (2008)) whereas the latter either depend on the composition of the melt (equations 14 and 15 of Putirka (2008)) or on the olivine-melt equilibrium (equations 22 and 21 of Putirka (2008)). We used a $K_{\mathrm{D}}(\mathrm{Fe}-\mathrm{Mg})^{\mathrm{ol}-\mathrm{liq}}=0.30 \pm 0.03$ (Roeder \& Emslie, 1970) as a test of equilibrium. The equations involving plagioclase were not considered at this stage because, as already stated above, its composition is controlled by several parameters thus precluding a simple equilibrium test. The temperature calculated with the $\mathrm{H}_{2} \mathrm{O}$ dependent equilibria strongly varies with the water content, that we allowed to increase from 0 to $4 \%$, whereas the temperature of the no- $\mathrm{H}_{2} \mathrm{O}$ term equilibria is nearly constant (a small change in the melt composition produced by the addition of an increasing amount of $\mathrm{H}_{2} \mathrm{O}$ induces a slight temperature variation). A maximum of 4 wt. $\% \mathrm{H}_{2} \mathrm{O}$ was considered based on the absence of amphibole in all La Picada samples. The intersection of the two groups of thermometers provides an estimation of the $\mathrm{H}_{2} \mathrm{O}$ content of the magma. In the case of the Calbuco volcano (Montalbano et al., 2017), the $\mathrm{H}_{2} \mathrm{O}$ contents derived from the Mandler test and measured in olivine-hosted melt inclusions agree suggesting that this test provides robust information. Calculations were performed at different pressures $(0.1,0.2,0.3$ and $0.4 \mathrm{GPa})$ for the High-MgO (PIC06, PIC50), Int-MgO ${ }^{+}$(PIC43) and Low-MgO (PIC30, PIC31) basaltic parent magmas (Table 4 and S8). In these calculations, the bulk rock compositions of the basalts were interpreted as representative of liquid compositions as they are in equilibrium with the cores of the olivine (Fig. 7). Total $\mathrm{FeO}$ was used as the effect of the $\mathrm{Fe}^{3+} / \mathrm{Fe}^{2+}$ ratio is negligeable 
on temperature calculated with the olivine thermometers. Indeed, nearly identical temperatures and wt. $\% \mathrm{H}_{2} \mathrm{O}$ were obtained for the basalt PIC43 when considering total $\mathrm{FeO}$ or a $\mathrm{FeO}$ fraction of 0.9 , appropriate for oxygen fugacities between FMQ and NNO (Putirka, 2008) (see Table S8). Results indicate a liquidus temperature range of about 1140 to $1180^{\circ} \mathrm{C}\left( \pm 10^{\circ} \mathrm{C}\right)$ and an $\mathrm{H}_{2} \mathrm{O}$ content varying from 1.0 to 1.5 wt. $\%$ ( \pm 0.3 wt. $\%)$ at $0.2 \mathrm{GPa}$ among the different basalts. This temperature range is in agreement with experimental data performed on starting compositions similar to the La Picada basalts (Blatter et al., 2013; Draper \& Johnston, 1992; Hamada \& Fujii, 2008; Nandedkar et al., 2014). The plagioclase hygrometer proposed by Waters \& Lange (2015) was then used to further constrain the water content of the magma given that its standard error estimate (SEE) is 0.35 wt. $\% \mathrm{H}_{2} \mathrm{O}$. As this hygrometer depends strongly on temperature and plagioclase composition but slightly on pressure, the $\mathrm{H}_{2} \mathrm{O}$ content was calculated at $0.2 \mathrm{GPa}$ using, for each basalt, the temperature obtained with the procedure of Mandler et al. (2014) at this pressure and the range of composition measured in the plagioclase cores of the basalts $\left(\mathrm{X}_{\mathrm{An}}=0.9\right.$ to 0.8$)$ (Fig. 5a: Table 5). The choice of the plagioclase cores composition is supported by two observations made for olivine. Firstly, the Fo-rich cores are in equilibrium with the bulk rock composition and secondly, olivine has a higher Fo content in the High-MgO samples compared to the olivine of the Low-MgO samples (Fig. 7). Calculated $\mathrm{H}_{2} \mathrm{O}$ contents are higher than the estimations from the Mandler et al. (2014) test, except for PIC06, and suggest a slight difference between the High-MgO $\left(0.9-1.8\right.$ wt. $\left.\% \mathrm{H}_{2} \mathrm{O}\right)$ and Low-MgO basalts (2.3-3.1 wt. $\left.\% \mathrm{H}_{2} \mathrm{O}\right)$. Given the SEE of the plagioclase hygrometer $\left( \pm 0.35\right.$ wt. $\left.\% \mathrm{H}_{2} \mathrm{O}\right)$, this increase seems to be significant but small. In the following, we will use the $\mathrm{H}_{2} \mathrm{O}$ content calculated with $\mathrm{An}_{90}$ and the upper temperature of the Mandler et al. (2014) test: $2.5 \%$ (Low-MgO), 1.5\% (Int-MgO+), 
$1.1 \%$ (High $\mathrm{MgO}$ ). These water contents are lower than or at the lower limit of the 26 wt. $\% \mathrm{H}_{2} \mathrm{O}$ range obtained for mafic arc magmas in a series of volcanic arcs (Cascades, Aleutians, Mexico, Marianas, Kamchatka, Tonga, Centam) (Plank et al., 2013) but are in agreement with the observed mineralogy. The absence of amphibole indeed indicates an $\mathrm{H}_{2} \mathrm{O}$ content lower than 4-6 wt \% in the differentiated facies (e.g. Andújar et al., 2015; Sisson \& Grove, 1993) translating into a maximum of 1.6 to 2.4 wt. $\% \mathrm{H}_{2} \mathrm{O}$ in the parent magmas if $60 \%$ differentiation (fraction of residual liquid $=$ 0.4 ) is considered (see below). They are also concordant with results from Watt et al. (2013) who measured water contents between 1.3 and 2.1 wt. \% in olivine-hosted melt inclusions from several volcanoes of the SVZ (Hornopiren, South Michinmavida and Palena) (Fig. 1). We have no precise constraints on the $\mathrm{CO}_{2}$ content of the $\mathrm{La}$ Picada magmas as pyroclasts unequivocally belonging to this volcano and carrying olivine with glassy melt inclusions were not recognized in the field. However, the highest $\mathrm{CO}_{2}$ content reported by Watt et al. (2013) for their set of melt inclusions is $1238 \mathrm{ppm}$. The pressure of volatile saturation was thus estimated with the VolatileCalc_2.0 model of Newman \& Lowenstern (2002) using an $\mathrm{H}_{2} \mathrm{O}$ and $\mathrm{CO}_{2}$ content of respectively 1.1 to $2.5 \mathrm{wt} . \%$ and $1200 \mathrm{ppm}$ and a temperature range of $1140-1180^{\circ} \mathrm{C}$. Results indicate that in these conditions the La Picada magmas were volatile saturated at $0.25-0.3 \mathrm{GPa}$. Volatiles exsolution increases the viscosity of the magma as it promotes the polymerization of the melt structure and crystallization. However, it should also reduce the bulk density of the so produced vesicular magma. Consequently, if volatile exsolution indeed favored the stalling of the magma at about $0.2 \mathrm{GPa}$ (Plank et al., 2013), it suggests that the proportion of bubbles in the magma was never large and/or that the density contrast between fluid and melt was lower at that depth. As mentioned above the presence of the intracrustal discontinuity at this 
pressure range is also a likely controlling factor and it is possible that volatiles exsolution and crustal structure played a role concomitantly.

The oxygen fugacity was estimated with the temperature derived from the thermometers used in the Mandler et al. (2014) test and the composition of the titanomagnetite. Estimates range from QFM+0.5 (PIC14 at $1098^{\circ} \mathrm{C}, \mathrm{PIC} 50$ at $\left.1175^{\circ} \mathrm{C}\right)$ to $\mathrm{QFM}+0.2\left(\mathrm{PIC} 33\right.$ at $\left.1067^{\circ} \mathrm{C}\right)$. Andújar et al. (2015) experimentally studied the Balos basalt from Santorini that is very close in composition to our sample PIC50. Using their experimental results, these authors derived an empirical equation giving the forsterite content of the olivine as a function of temperature, $\mathrm{H}_{2} \mathrm{O}$ content of the melt and oxygen fugacity: Fo $(\mathrm{mol} \%)=0.1037 \times \mathrm{T}\left({ }^{\circ} \mathrm{C}\right)+1.7638 \times \mathrm{H}_{2} \mathrm{O}_{\text {melt }}(\mathrm{wt}$ $\%)+3.0234 \times \Delta \mathrm{NNO}-38.63$. Considering the composition of olivine in PIC50 $\left(\mathrm{F} 0_{85}\right)$, a temperature of $1175^{\circ} \mathrm{C}$ derived from the Mandler et al. (2014) test and an $\mathrm{H}_{2} \mathrm{O}$ content varying from 1.1 to $1.8 \mathrm{wt}$. \%, the calculated oxygen fugacity is NNO0.1 to NNO- 0.5 corresponding to $\mathrm{QFM}+0.8$ and $\mathrm{QFM}+0.40$, respectively. These values overlap with those derived with the titanomagnetite composition and agree with the oxygen fugacity generally obtained for basalts that straddle the tholeiiticcalc-alkaline boundary (Sisson et al., 2005). In the following, we will consider an oxygen fugacity of QFM+0.5, close to NNO.

\section{DISCUSSION}

\section{Geochemical variability at La Picada}

As detailed above, basalts and basaltic andesites at La Picada display variable $\mathrm{MgO}$, $\mathrm{Al}_{2} \mathrm{O}_{3}, \mathrm{Cr}$ and $\mathrm{Ni}$ contents at a given $\mathrm{SiO}_{2}$ content, justifying the distinction between 
High-, Low- and Int-MgO samples (Figs 8 and 9). In the following, we will discuss three processes that could potentially explain this observation: (1) preferential entrainment of plagioclase or ferromagnesian macrocrysts from the magma storage's crystal mush, inducing lower $\mathrm{MgO}, \mathrm{Cr}, \mathrm{Ni}$ and higher $\mathrm{Al}_{2} \mathrm{O}_{3}$ contents in the LowMgO samples; (2) differentiation of the same parent magma at different pressures, as higher pressure respectively expands and decreases the stability fields of clinopyroxene and plagioclase thus inducing lower MgO (Yoder, 1976); and (3) variable extent of fractional crystallization of the same parent magma. Entrainment of macrocrysts is probably not a reasonable assumption as it would produce more scattered data. It has nonetheless been tested quantitatively as the relative proportions of plagioclase and ferromagnesian minerals are slightly higher in the Low-MgO samples than in the High-MgO samples (Fig. 15). We have thus verified if adding 5\% to $10 \%$ plagioclase to the composition of the High- $\mathrm{MgO}$ basalt could reproduce the composition of the Low-MgO basalt. Results are presented in Table 6a. The trace element content of a plagioclase in equilibrium with the High- $\mathrm{MgO}$ basalt was calculated using the trace element content of basalt PIC50 (High-MgO) and appropriate partition coefficients (see Table 10 below). Eu and $\mathrm{Sr}$ are commonly used as a test for plagioclase accumulation because plagioclase preferentially incorporates these elements. However, we note that, as the calculated Eu and $\mathrm{Sr}$ contents of plagioclase are respectively low and moderate (Table 6a), loading the High-MgO basalt with plagioclase does not have much effect on the resulting Eu and $\mathrm{Sr}$ contents of the magma. Consequently, the similar Sr (Fig. 9) and REE (Fig. 10) patterns of the High- and Low-MgO samples does not necessarily preclude plagioclase accumulation. Contrarily, results clearly indicate that $\mathrm{FeO}_{\mathrm{t}}, \mathrm{MnO}, \mathrm{Cr}$ and $\mathrm{Ni}$ are too high in the calculated composition compared to the Low-MgO samples. 
Consequently, even if some plagioclase accumulation may have occurred in the Low$\mathrm{MgO}$ samples, as suggested by their higher proportion of plagioclase, this process cannot take into account the geochemical variability at La Picada. We have also tested the possibility that different entrainment of olivine and clinopyroxene produced the variable $\mathrm{MgO}, \mathrm{Al}_{2} \mathrm{O}_{3}, \mathrm{Cr}$ and $\mathrm{Ni}$ contents (titanomagnetite was not considered as it is not present as macrocrysts in the basalts and basaltic andesites). As $\mathrm{Ni}$ is preferentially incorporated in olivine and clinopyroxene, whereas $\mathrm{Cr}$ substitutes in clinopyroxene, these trace elements were used to calculate the amount of olivine and clinopyroxene that must be added to the composition of the Low-MgO basalt in order to obtain the observed $\mathrm{Ni}$ and $\mathrm{Cr}$ contents of the High-MgO basalt. These calculated proportions were then used to test if they can explain the different $\mathrm{MgO}$ and $\mathrm{Al}_{2} \mathrm{O}_{3}$ contents of the Low- and High-MgO samples. Results indicate that the calculated proportions of olivine (6\%) and clinopyroxene (18\%) added to the Low-MgO basalt fail to reproduce the observed $\mathrm{MgO}$ and $\mathrm{Al}_{2} \mathrm{O}_{3}$ contents of the High-MgO basalt (Table 6b). Preferential entrainment of macrocrysts cannot thus be retained as an explanation for the compositional diversity at a given $\mathrm{SiO}_{2}$. The higher Fo content of olivine cores in the High-MgO samples, indicating equilibrium with a more magnesian melt, supports this conclusion. It is also worth noting that the high mass proportions of plagioclase in the La Picada lavas (Fig. 15) are very similar to the relative abundances of plagioclase and olivine $\left(\mathrm{Plag}_{70}: \mathrm{Ol}_{30}\right)$ typically observed in the cumulus assemblages of many mafic layered intrusions (e.g. Rhum intrusion, Brown (1956); Kiglapait intrusion, Morse (1979); Sept Iles Layered Intrusion, Namur et al. (2011)) and calculated from experimental data (e.g. Grove \& Baker, 1984; Toplis \& Carroll, 1995). 
Several experimental studies (e.g. Draper \& Johnston, 1992; Grove et al., 2003; Müntener et al., 2001) have demonstrated that with increasing pressure, the stability field of clinopyroxene and plagioclase respectively expands and decreases. Moreover, at high pressure, garnet becomes stable. Here, we focus on the experiments of Draper \& Johnston (1992) (1 atm, 1, 1.2, 1.5, 2 GPa: anhydrous conditions) because their starting composition is very close to the La Picada basalts. Their dataset indicate that the composition of the liquids becomes increasingly enriched in $\mathrm{Na}_{2} \mathrm{O}$ and $\mathrm{K}_{2} \mathrm{O}$ and depleted in $\mathrm{CaO}$ with increasing pressure. The different samples of $\mathrm{La}$ Picada overlap for these three elements (Fig. 8) and are similar to the 1 atm liquid line of descent of Draper \& Johnston (1992). Moreover, the experimental fractionation trend obtained at $0.4 \mathrm{GPa}$ by Blatter et al. (2013) on a starting composition very close to the parent magma of La Picada, except that it is slightly higher in $\mathrm{P}_{2} \mathrm{O}_{5}, \mathrm{Na}_{2} \mathrm{O}$ and $\mathrm{TiO}_{2}$ and slightly lower in $\mathrm{Al}_{2} \mathrm{O}_{3}$ and $\mathrm{CaO}$, also reproduces the trend observed in this study (Fig. 16). These upper crustal pressures are also in agreement with results obtained with the cpx-melt geobarometer. Thus fractionation at significantly different pressures cannot predict the geochemical variability. We have further tested the hypothesis of fractionation at slightly different pressures, between 0.2 and $0.4 \mathrm{GPa}$, by simulating the fractional crystallization of the PIC50 basalt (High-MgO) with the Rhyolite-Melts algorithm (Ghiorso \& Gualda, 2015; Gualda et al., 2012) at an oxygen fugacity of NNO and with $1.5 \mathrm{wt} \% \mathrm{H}_{2} \mathrm{O}$ in the starting composition. Results are illustrated in Fig. 16. $\mathrm{MgO}$ is indeed lower at $0.4 \mathrm{GPa}$ and reaches the Low-MgO basalts after some fractionation of olivine and plagioclase but at a higher $\mathrm{SiO}_{2}$. Also, the $0.2 \mathrm{GPa}$ trend is much lower in $\mathrm{Al}_{2} \mathrm{O}_{3}$ than the High-MgO samples. Finally, the $0.4 \mathrm{GPa}$ trend is respectively much lower and much higher in $\mathrm{CaO}$ and in $\mathrm{Na}_{2} \mathrm{O}$ than the Low-MgO samples because of clinopyroxene fractionation. In conclusion, 
fractionation at different pressures does not appear plausible especially because the different trends of La Picada should have different $\mathrm{Na}_{2} \mathrm{O}$ content as this element is strongly influenced by the decreasing stability field of plagioclase with pressure (Fig. 8).

When using a perfectly incompatible element such as $\mathrm{Zr}$ as the differentiation index (Supplementary figure S9), the La Picada samples define a continuous trend of decreasing $\mathrm{MgO}$, $\mathrm{Ni}$ and $\mathrm{Cr}$ with increasing $\mathrm{Zr}$ suggesting that differentiation can

predict the occurrence of the High- and Low-MgO basalts. A fractional crystallization model (see below, S9) indeed perfectly fits the Ni-Zr data. Interestingly, when incompatible elements like $\mathrm{Rb}, \mathrm{La}$ or $\mathrm{Ba}$ are used as the differentiation index, the data are more scattered maybe because these elements are variably contributed by the slab component among the La Picada samples whereas $\mathrm{Zr}$ is a "conservative" element (Pearce \& Peate, 1995) (Fig.11). We thus conclude that the High- and Low-MgO basalts result from a different extent of fractionation.

\section{Mantle melting conditions under La Picada}

The mantle melting conditions under La Picada were estimated with the Lee et al. (2009) and Putirka (2008) (equations 42, 13 and 14) geothermobarometers and the approach of Kelley et al. (2006) and Kelley et al. (2010). The Lee et al. (2009) and Putirka (2008) (equation 42) geothermobarometers are based on the equilibrium between a basaltic melt, olivine and orthopyroxene. They are thus appropriate here as primary basalts equilibrate with these minerals in their mantle source. The representative composition of the parent magmas was calculated as the average composition of samples PIC04, 05 and 06 for the High-MgO basalts and of samples 
PIC30 and PIC31 for the Low-MgO basalts. The High-MgO sample PIC50 was also selected. Their Mg\# lower than 0.7 (e.g. Grove et al., 2012) (0.6 for the High-MgO, 0.56 for the Low-MgO, 0.61 for PIC50) and $\mathrm{Cr}$ (202 for the High-MgO, 110 for the Low-MgO, 232 for PIC50) and Ni (71 for the High-MgO, 45 for the Low-MgO, 99 for PIC50) contents respectively lower than $232 \mathrm{ppm}$ and $99 \mathrm{ppm}$ preclude them to be primary magmas in equilibrium with a mantle source ( $>1000 \mathrm{ppm} \mathrm{Cr}, 400-500 \mathrm{ppm}$ Ni). In order to estimate the temperature and pressure of last equilibration with the mantle source using the Lee et al. (2009) and Putirka (2008) (equations 42, 13 and 14) geothermobarometers, we have thus corrected the composition of the parent magmas in the following way. The experimental data of Draper \& Johnston (1992) used sample ID-16, a primary magma from the Aleutian arc (Grove et al., 2012), as a starting composition. At $1 \mathrm{~atm}$, after $20.6 \%$ cristallization of a troctolitic cumulate ( $53.40 \%$ olivine $+46.60 \%$ plagioclase) from this sample, the residual liquid is very close in composition to the La Picada basalts. We have thus added $20.6 \%$ of this cumulate to the composition of the La Picada parent magmas using olivine (Fo86) and plagioclase $\left(\mathrm{An}_{88}\right.$ for the High-MgO, $\mathrm{An}_{92}$ for the Low-MgO, $\mathrm{An}_{90}$ for PIC50) core compositions in order to reach the composition of a liquid in equilibrium with olivine only. Two percent of olivine (Fo8s from Draper \& Johnston, 1992) were then added to obtain the composition of near primary magmas with $\mathrm{MgO}$ contents ranging from 10.68 wt. $\%$ to 11.73 wt. \% appropriate for the use of the Lee et al. (2009) geothermobarometer (Table 7). Their $\mathrm{H}_{2} \mathrm{O}$ content (0.9 to 2.0 wt. \%) was calculated using results obtained with the Waters \& Lange (2015) hygrometer on the basalts and taking into account the added cumulates (Table 7). They represent minimum values if the basaltic parent magmas reached vapor saturation and started degassing at a slightly higher pressure than $0.2 \mathrm{GPa}$. This correction procedure relies on the 
hypothesis that the differentiation of the near primary magma to the basaltic parent magma took place in the upper crust as the $1 \mathrm{~atm}$ experimental data were used. However, as this part of the differentiation could have taken place close to the $\mathrm{MOHO}$, we have tested the same procedure using the experimental dataset of Müntener et al. (2001) where phase equilibria of primary arc magmas were studied at 1.2 GPa, conditions corresponding to the arc lower crust. Adding $16.5 \%$ of their B736 cumulate $(52.12 \%$ olivine $+46.06 \% \mathrm{cpx}+1.82 \% \mathrm{opx})$ to the composition of the PIC50 basalt results in calculated pressure and temperature that are within errors of those deduced with the above procedure. We acknowledge that this procedure represents a significant correction but we however think that the close compositional similarity between the La Picada samples and the experimental melts provides some robustness to these calculations. The composition of primary magmas in equilibrium with olivine Fo90 was then obtained by incremental addition of olivine to the compositions of the near primary magmas using the Lee et al. (2009) algorithm. Their $\mathrm{MgO}$ content ranges from 12.37 to 13.02 wt. \% (Table 7), they are thus close to picritic compositions. Temperatures $\left(1321^{\circ} \mathrm{C}\right.$ to $\left.1341^{\circ} \mathrm{C}\right)$ and pressures $(1.2$ to 1.4 GPa) calculated with the Lee et al. (2009) geothermobarometer overlap within uncertainties for the different samples $\left( \pm 50^{\circ} \mathrm{C}, \pm 0.2 \mathrm{GPa}\right)$ (Table 7). Temperatures and pressures obtained with equations $13\left(1320^{\circ} \mathrm{C}\right.$ to $\left.1337^{\circ} \mathrm{C}\right), 14\left(1315^{\circ} \mathrm{C}\right.$ to $\left.1329^{\circ} \mathrm{C}\right)$ and $42(1.2$ to $1.4 \mathrm{GPa})$ of Putirka $(2008)$ agree within errors $\left( \pm 51 / 71^{\circ} \mathrm{C}, \pm\right.$ 0.3GPa) with those derived from the Lee et al. (2009) geothermobarometer (Table 7). These P-T conditions are higher than the dry peridotite solidus of Hirschmann (2000) suggesting that adiabatic decompression melting could have taken place (Fig. 17a). However this doesn't preclude flux melting as the basaltic parent magmas at La Picada are clearly enriched in slab derived components compared to MORBs (Fig. 
11). $\mathrm{P}$ and $\mathrm{T}$ obtained for La Picada overlap with those calculated by Watt et al. (2013) for volcanic centers (Hornopiren, Apagado, Palena, South Minchinmavida) located further south on the Andean arc, using the composition of olivine hosted melt inclusions corrected for post entrapment crystallization and fractionation (Fig. 17a). The extent of mantle melting (F) and the $\mathrm{H}_{2} \mathrm{O}$ content of the mantle source $\left(C_{\mathrm{H} 2 \mathrm{O}}^{0}\right)$ can be constrained with a batch melting equation including the $\mathrm{TiO}_{2}$ content of the primary magmas $\left(C_{\mathrm{TiO} 2}^{l}\right)$ and estimations of $\mathrm{D}_{\mathrm{TiO} 2}(0.04$ : Kelley et al., 2006) and $C_{\text {TiO2 }}^{0}\left(\mathrm{TiO}_{2}\right.$ concentration of the mantle source) following the methodology proposed by Kelley et al. (2006) and Kelley et al. (2010) $\left(F=\frac{\left({ }^{C_{T i O 2}} / C_{T i O 2}^{l}-D_{T i O 2}\right)}{\left(1-D_{T i O 2}\right)}\right)$. This approach is based on the recognition that, as a "conservative" element (Pearce \& Peate, 1995), $\mathrm{TiO}_{2}$ in the arc melts is solely contributed by the mantle source and is immobile in the slab component (Kelley et al., 2010). The main unknown is $C_{\text {TiO2 }}^{0}$. It was estimated in two ways. Firstly, we considered a constant $\mathrm{TiO}_{2}$ content of 0.133 wt. \% (Salters \& Stracke, 2004). Secondly, we followed the procedure of Kelley et al. (2006) that uses the $\mathrm{TiO}_{2} / \mathrm{Y}$ of MORBs. Because these two elements have similar partition coefficients during mantle melting beneath ridges, this ratio shows limited variation in MORBs (0.04-0.05: Kelley et al., 2006) and Kelley et al. (2006) considered that higher $\mathrm{TiO}_{2} / \mathrm{Y}$ in enriched mantle sources are solely due to enrichment in $\mathrm{TiO}_{2}$ thus enabling the calculation of $C_{\mathrm{TiO2} 2}^{0}\left(C_{\mathrm{TiO2} 2}^{0}=\frac{\left(\frac{\mathrm{TiO} 2}{\mathrm{Y}}\right) \text { sample }}{\left(\frac{\mathrm{TiO2}}{\mathrm{Y}}\right) \mathrm{MORB}}\right.$ $C_{\text {TiO2 }}^{D M M}$ with $\left(\frac{\text { TiO2 }}{Y}\right)$ in MORB $=0.04$ and $\left.C_{\text {TiO2 }}^{D M M}=0.133\right)$. The extent of melting $(\mathrm{F})$ can then be used in the batch melting equation to derive the $\mathrm{H}_{2} \mathrm{O}$ content of the mantle source knowing the $\mathrm{H}_{2} \mathrm{O}$ content of the primary magmas and $\mathrm{D}_{\mathrm{H} 2 \mathrm{O}}(0.01$ : Kelley et al., 2006). F values derived with a constant $\mathrm{TiO}_{2}(0.15$ to $0.18:$ Table 7$)$ are not 
significantly lower than those derived with the calculated $\mathrm{TiO}_{2}(0.16$ to 0.22$)$. The $\mathrm{F}$ values of the different samples overlap within errors $( \pm 0.03)$ (Kelley et al., 2010) (Table 7, Fig. 17b). However, their restricted range combined with the variable $(\mathrm{La} / \mathrm{Yb})_{\mathrm{N}}$ ratios (Fig. 11d) point to a possible variation of the extent of mantle partial melting among the samples.

Given the uncertainty on $C_{H 2 O}^{0}\left( \pm 0.10 \%\right.$ ) (Kelley et al., 2010), the $\mathrm{H}_{2} \mathrm{O}$ content of the mantle source seems to overlap for the different samples of La Picada ( 0.2 to $0.3 \mathrm{wt} \%$ $\mathrm{H}_{2} \mathrm{O}$ for the constant and calculated $C_{\text {TiO2 }}^{0}$ : Table 7, Fig. 17b). Our results agree with those obtained by Watt et al. (2013) for the $\mathrm{SVZ}\left(C_{\mathrm{H} 2 \mathrm{O}}^{0}=0.2-0.6\right.$ wt. $\left.\% \mathrm{H}_{2} \mathrm{O}\right)$ and by Portnyagin et al. (2007) for the Kamchatkan arc magmas $\left(C_{H 2 O}^{0}=0.1-0.4\right.$ wt. \% $\mathrm{H}_{2} \mathrm{O}$ ). Estimates of slab-surface temperatures with $\mathrm{Ce}$ and $\mathrm{K}$ geothermometry (Cooper et al., 2012; Plank et al., 2009) range from 791 to $920^{\circ} \mathrm{C}$ (Table 8) and are above the wet-sediment solidus $\left(700^{\circ} \mathrm{C}\right.$ at about $3 \mathrm{GPa}$ for a pelitic sediment (Hermann $\&$ Spandler, 2008); $750^{\circ} \mathrm{C}$ for a basaltic composition (Lambert \& Wyllie, 1972)) suggesting a melt-dominated flux in agreement with trace element data (low $\mathrm{Ba} / \mathrm{Th}$; Fig. $11 \mathrm{~b})$. A similar temperature $\left(870^{\circ} \mathrm{C}\right)$ was obtained by Watt et al. (2013) for the Hornopiren-Apagado-Palena-South Minchinmavida rear arc volcanoes. We currently have no precise constraints on where the differentiation from the primary magmas to the basaltic parent magmas took place. Nonetheless, we note that given their calculated $\mathrm{MgO}$ (12.37 to 13.02 wt. \%) and $\mathrm{H}_{2} \mathrm{O}$ (1 to 2 wt. \%, Table 7) contents, these primary magmas could have fractionated close to the limit between the lower and upper crust according to Putirka (2017) (their Fig. 3). Moreover, as garnet is replacing plagioclase at high pressure and incorporates HREE and Y but not $\mathrm{Sr}$ (e.g. Chapman et al., 2015), the low $\mathrm{La}_{\mathrm{N}} / \mathrm{Yb}_{\mathrm{N}}(1.47$ to 2.49 , Table 1$)$ and $\mathrm{Sr} / \mathrm{Y}$ (18 to 27, Table 1) ratios of the basaltic parent magmas don't support high pressure 
fractionation. The occurrence of picritic lavas at the surface of Apagado (Watt et al., 2013) corroborates this hypothesis and even indicates that these highly magnesian magmas can eventually ascend to the upper crust without differentiation. However, given their high density, their fractionation at deeper levels cannot be completely ruled out.

The combination of all geothermobarometric data can be used to draw a schematic sketch of the subduction zone under La Picada, illustrating the estimated location of sub-arc magmatic processes that determine the composition of the magmas (Fig. 18).

\section{Magma differentiation processes}

A striking characteristic of the La Picada trends is the occurrence of a Daly gap. In the following we will discuss first the differentiation processes that produced the geochemical variability from basalts to basaltic andesites and then the possible causes of this Daly gap. As shown on Fig. 16, the La Picada trend overlaps with experimental melts and trends calculated with Rhyolite-Melts (Ghiorso \& Gualda, 2015; Gualda et $a l ., 2012)$ at $0.2 \mathrm{GPa}$ suggesting that even if some plagioclase accumulation may have occurred and in contrast with the textural complexity of the basaltic andesites (Fig. 4), the whole-rocks trend can be considered as representative of a liquid line of descent, a paradox already emphasized by Cashman \& Blundy (2013). As shown above, clinopyroxenes in equilibrium with the bulk rock indicate that the differentiation processes took place in the upper crust. 
Magma mixing and fractional crystallization are the most plausible processes that could produce the chemical diversity between the basalts and the basaltic andesites. It is possible that some contamination occurred in the main magma storage region as gabbroic fragments such as sample PIC11 dated at 9 Ma, have locally been observed. However, these gabbros have overlapping compositions with the La Picada lavas for most major and trace elements (Supplementary figure S6). Consequently, their assimilation, if it indeed occurred, has probably not significantly affected the composition of the lavas. Isotopic data are not available for the La Picada samples but here too the gabbroic fragments and the lavas are likely to have overlapping isotopic ratios (Dungan \& Davidson, 2004).

Discrimination between mixing and fractional crystallization is hampered by the restricted compositional range from basalt to basaltic andesite (about $5 \mathrm{wt}$. \% $\mathrm{SiO}_{2}$ ) as curved trends produced by fractional crystallization are usually developped within a much larger range. A potential mixing process has been tested with samples PIC43 (51.27 wt. \% $\mathrm{SiO}_{2}$ ) and $\mathrm{PIC} 44$ (56.23 wt. \% $\mathrm{SiO}_{2}$ ) representing respectively the mafic and acid endmembers whereas PIC13 (53.72 wt. \% $\mathrm{SiO}_{2}$ ) was considered as possibly resulting from the mixing between these two facies. These three samples were chosen because they are aligned in most variation diagrams. The mixing process was tested with the Fourcade \& Allègre (1981) method:

$$
X=\frac{C_{i n t}-C_{a}}{C_{b}-C_{a}}
$$

where $\mathrm{x}$ is the fraction of the mafic endmember, $\mathrm{C}_{\mathrm{a}}$ and $\mathrm{C}_{\mathrm{b}}$ are respectively the composition of the acid and mafic endmembers, and $\mathrm{C}_{\mathrm{int}}$ is the composition of the mixed facies. If a mixing process did occur, $\mathrm{X}$ should have a value between 0 and 1 and should be the same for all major and trace elements. In the case of the selected samples, Fig. 19 a-b shows that most elements plot on the same line in the $C_{\text {int }}-C_{a}$ 
vs. $C_{b}-C_{a}$ diagram with a plausible value of 0.63 for X. However, several elements ( $\mathrm{Rb}, \mathrm{Zr}, \mathrm{Cu}, \mathrm{Ni}, \mathrm{Sr}, \mathrm{Ba}, \mathrm{Ce}, \mathrm{Pb}, \mathrm{Co}, \mathrm{Sc}, \mathrm{Ga}, \mathrm{Y}, \mathrm{SiO}_{2}$ ) do not plot on the same line indicating that a mixing process cannot take into account the complete dataset. If we consider the full differentiation trend from the basalts to the dacites, mixing between a dacite and a basalt to produce a basaltic andesitic composition appears plausible as a few samples plot slightly out of the curved trend shown in the $\mathrm{Zr}$ vs.Ni diagram (Supplementary figure S9). However, here too, we note that a mixing process fails to predict all major and trace elements data (Fig. 19 c-d). As mentioned above, the larger scatter observed in the $\mathrm{Rb}$ vs. $\mathrm{Ni}, \mathrm{La}$ vs. $\mathrm{Ni}$ and $\mathrm{Ba}$ vs. Ni diagrams (S9) is interpreted as resulting from parent magmas with slightly variable incompatible elements ratios among the La Picada samples (Fig. 11). This could be due to variable mantle source composition (variable contribution of the slab component ?) or to slightly variable extent of mantle partial melting.

Fractional crystallization is supported by several observations. In variation diagrams using two incompatible elements, Ta and $\mathrm{Rb}$ as well as Ta and Th (Fig. 20 a and b), samples are slightly scattered but define linear trends passing through the origin. In $\log (\mathrm{Ni})-\log (\mathrm{Rb})$ and $\log (\mathrm{Y})-\log (\mathrm{Rb})$ diagrams (Fig. $20 \mathrm{c}$ and d), samples are here too slightly scattered but define linear trends in agreement with the Rayleigh distillation law. Finally, in Zr vs. Ni and Zr vs. Cr diagrams (S9), if the dykes 1 dacites are included, samples define a curved trend with a rapid depletion in $\mathrm{Ni}$ and Cr. On the other hand, the experimental melts of Draper \& Johnston (1992) at 1 atm overlap with the La Picada trend providing an additional support to a fractional crystallization process. 
The fractional crystallization process was modelled in two steps, using the least square regression method on basalts and basaltic andesites. Subtraction of a gabbroic cumulate from the basaltic parent magma (PIC43) drives the liquid to the composition of a basaltic andesite (PIC34) after 33\% fractionation (Table 9). In a second step, separation of a gabbronoritic cumulate produces a residual liquid with the composition of the most evolved basaltic andesite (PIC44) after 15\% fractionation. The total fractionation is $43 \%$.

Results from the least square regression model, i.e. fraction of residual liquid and proportions of phases in the cumulates at each step, can be tested using the trace element composition and the calculated bulk partition coefficients in the Rayleigh distillation law:

$$
C_{L}=C_{0} \cdot F^{(\mathrm{D}-1)}
$$

where $\mathrm{C}_{0}$ and $\mathrm{C}_{\mathrm{L}}$ are, respectively, the concentration of the trace element in the parent magma and in the residual liquid, $\mathrm{F}$ is the fraction of residual liquid and $\mathrm{D}$ is the bulk partition coefficient of the trace element; $\mathrm{D}=\sum X_{i} . D_{i}$ where $\mathrm{X}_{\mathrm{i}}$ is the mass fraction of a given mineral in the cumulates and $D_{i}$ is the partition coefficient of trace element $i$ between this mineral and the liquid. Partition coefficients that were used in this test are given in Table 10. The calculated trace element composition of the residual liquids (Table 11) compares very well with the observed ones especially for transition elements that are compatible during differentiation. REE are not well reproduced in the second step as the calculated contents are higher than the observed ones. Samples PIC43 and PIC34 selected in the first step have higher REE content than most other samples of the Int-MgO trend, including the most evolved sample (PIC44). For example, PIC43 (51.27 wt. \% $\mathrm{SiO}_{2}$ ) has 20.1 ppm Ce compared to $13.2 \mathrm{ppm}$ in 
sample PIC09 that has a comparable $\mathrm{SiO}_{2}$ content (52.68 wt. \% $\mathrm{SiO}_{2}$ ). If 13 ppm of

Ce are considered in the parent magma at step 1, the calculated residual liquid has 19 ppm $\mathrm{Ce}$ and using this value as the starting composition at step 2, the calculated residual liquid has $22 \mathrm{ppm}$ Ce that closely matches the $21 \mathrm{ppm}$ Ce in PIC44.

Origin of the dacites and of the Daly gap

The dacites. As previously mentioned, two groups of dacites displaying similar mineralogy (few macrocrysts of plagioclase, orthopyroxene and clinopyroxene in a glassy matrix; Fig. 4), have been distinguished based on their trace elements content. In Harker diagrams with HFSE (Zr, HF, Nb, Ta, Th, U, Y, TR) and LILE $(\mathrm{Rb}, \mathrm{Ba}, \mathrm{Cs})$, dykes 2 dacites are above the main trend. However, both groups of dacites can be extrapolated from the basalts-basaltic andesites trend for major and transition elements ( $\mathrm{Sc}, \mathrm{Cr}, \mathrm{V}, \mathrm{Cr}, \mathrm{Ni}, \mathrm{Co}, \mathrm{Zn})$ as well as for $\mathrm{Ga}$. When pairs of incompatible elements are plotted, dykes 1 dacites are aligned with the basalts and basaltic andesites (Fig. 20 a and b) whereas dykes 2 dacites define a distinct group except for Th and Rb (Fig. 9). Dykes 2 dacites are indeed twice more enriched than dykes 1 dacites in both $\mathrm{Rb}$ and $\mathrm{Th}$, resulting in a constant $\mathrm{Rb} / \mathrm{Th}$ ratio in all samples of La Picada. The incompatible trace elements composition thus indicate that dykes 1 dacites could be produced by fractional crystallization from the basalts of La Picada but not dykes 2 dacites. As the dacites from the nearby Calbuco and Osorno volcanoes are compositionally similar to the dykes 1 dacites (Figs 8 and 9), in the current state of knowledge, the dykes 2 dacites cannot be linked to these volcanoes. Lopez-Escobar et al. (1995) reported that some mafic facies belonging to small volcanic centers located east of La Picada, Osorno and Calbuco on the Liquiñe-Ofqui 
Fault zone and referred to as the Minor Eruptive Centers (MEC) are characterized by higher $\mathrm{Ba}, \mathrm{Sr}, \mathrm{Zr}$, $\mathrm{Nb}$ than major volcanoes of this area (Supplementary figure S6). It is thus possible that the dykes 2 dacites could be correlated with these mafic facies.

The Daly gap. The initial recognition by Bunsen (1851) and Daly (1914) of a compositional Daly gap giving rise to bimodal mafic-silicic suites was later confirmed in many calc-alkaline, alkaline and tholeiitic magmatic suites and more recently, Reubi \& Blundy (2009) pointed out that in arc magmas, melt inclusions indeed display a bimodal distribution of composition with a significantly low amount of andesitic melts. Several processes, not mutually exclusive, have been proposed to predict the occurrence of a Daly gap: partial melting of country rocks induced by the emplacement of mafic liquids and producing the silicic compositions (e.g. Chayes, 1963), a non uniform compositional distribution of differentiated melts during lower crustal differentiation (Melekhova et al., 2013), bimodality of melts ascending from the lower crust (Reubi \& Blundy, 2009), rapid variation in the liquid composition for small temperature decrease resulting in a small amount of intermediate liquids (Grove \& Donnelly-Nolan, 1986), the existence of an immiscibility field along the liquid line of descent (e.g. Charlier \& Grove, 2012), and finally a physical control that inihibits the eruption of intermediate compositions (e.g. Brophy, 1991). In the following, we will successively discuss the adequacy of these processes at La Picada.

The dykes 1 dacites and the glass pockets analysed in the basalts and basaltic andesites have overlapping major element composition (Supplementary figure S6). Moreover, the dykes 1 dacites are aligned with the basalt and basaltic andesite trend passing through the origin in X-Y plots using two incompatible elements and they define the end point of a curved trend in the $\mathrm{Ni}-\mathrm{Zr}$ and $\mathrm{Cr}-\mathrm{Zr}$ diagrams 
(Supplementary figure S9). These observations indicate that the composition of the dykes 1 dacites can be predicted by fractional crystallization from the basaltic andesites and don't support their origin by partial melting of the crust. As already mentioned, there is no indication that this fractionation process occurred in the lower crust because the $\mathrm{Na}_{2} \mathrm{O}$ and $\mathrm{K}_{2} \mathrm{O}$ content of the dykes 1 dacites is lower than the experimental high pressure trends (e.g. Draper \& Johnston, 1992). Moreover, the macrocrysts composition shows no sign of high pressure fractionation (Fig. 13). This implies that the Daly gap was produced during the upper crustal differentiation.

A low amount of intermediate liquids produced during fractionation of assemblages having a nearly flat liquidus slope in temperature-composition space, such as the opx-cpx-plag-magnetite assemblage of step 2 at La Picada (Table 9), was initially proposed by Grove \& Donnelly-Nolan (1986) to explain the Daly gap and is indeed plausible here. Two lines of evidence indicate that fractionation of the La Picada parent magma can produce andesitic melts. Firstly, one of the glass pocket analysed in the basalt PIC50 as well as the calculated composition of the basaltic andesite PIC33 matrix are andesitic (Supplementary figure S6). Secondly, in the experimental datasets of Blatter et al. (2013) and Andújar et al. (2015) performed on starting compositions that are relevant here, two melts are andesitic (Fig. 16).

Textural, mineralogical and geochemical data suggest that a physical control combining critical cristallinity and melt segregation might have produced the observed Daly gap. The dacites, that were only observed in dykes, are very poor in macrocrysts of a few clinopyroxene and dominant plagioclase with no or rare inclusions and only slight zoning (Fig. 4d). On the contrary, the basaltic andesites are very rich in crystals here too dominated by plagioclase, but displaying complex zoning and inclusions patterns (Fig. 4b). The fractional crystallization model indicates 
that the liquid reaches the composition of the most evolved basaltic andesite when the proportion of crystals is $43 \%$. This represents a minimum value as the parent magma may have been slightly more primitive than our least differentiated sample. This result agrees very well with experimental data, as in run 2380 of Blatter et al. (2013) where the proportion of crystals is $48 \%$ with a differentiation degree $\left(54.3\right.$ wt. $\left.\% \mathrm{SiO}_{2}\right)$ similar to the most evolved basaltic andesite (56.9 wt. \% $\mathrm{SiO}_{2}$ ) and a $\mathrm{H}_{2} \mathrm{O}$ content (3\%) identical to that deduced for the residual liquid of La Picada. Interestingly, the proportion of crystals is $43 \%$ in $\mathrm{PIC} 33$ (56.96 wt. \% $\mathrm{SiO}_{2}$ ), which corresponds to the value at which crystals start to form a connecting network (critical cristallinity). Marsh (1981) indeed suggested that critical cristallinity is reached when the proportion of crystals is 50 to $60 \%$, in agreement with the rigid percolation threshold of about 55\% crystals later proposed by Vigneresse et al. (1996) for the segregation of felsic magma. Moreover, Philpotts et al. (1998) showed that when the proportion of plagioclase crystals is high, critical cristallinity is reached at about $35 \%$ crystals. We thus suggest that when the composition of the magmas (bulk rock) reached the composition of the most evolved basaltic andesite, the proportion of crystals was high enough for the magma to behave like a solid, precluding its eruption and thus producing the Daly gap. As already mentioned the glass pockets represent melt compositions that are slightly more differentiated than the interstitial melt (matrix) that was initially present in the crystal mush because of microlite crystallization during final magma ascent. The calculated matrix of the most evolved basaltic andesite PIC33 is indeed andesitic compared to the dacitic glass pockets analysed in the basaltic andesites PIC07, PIC10, PIC14. However, because the magmas having a composition corresponding to the critical cristallinity treshold did not erupt and were probably slightly more differentiated than the most evolved basaltic andesite that we 
sampled, we suggest that their interstitial melts were probably close to a dacitic composition similar to the glass pockets. As these overlap in composition with the dacitic dykes-(Supplementary figure S6), we further propose that the interstitial melt (or a fraction of it) was extracted from the crystal mush, collected and emplaced as dykes. Such a situation is similar to what has been described for crystal-rich dacitic ignimbrites and their associated crystal-poor rhyolitic facies (e.g. Bachmann et al., 2002; Cashman \& Blundy, 2000) except that at La Picada, the volume of extracted melt was probably much lower (only two small dacitic domes have been mapped on the nearby Osorno volcano). Consequently, according to this hypothesis, the observed compositional gap would simply result from the subtraction of the crystal load from the basaltic andesitic magma and will be more visible for elements that are enriched in the crystals. Separation of a crystal matrix rich in plagioclase from the basaltic andesitic magma produces a significant compositional gap in $\mathrm{SiO}_{2}, \mathrm{CaO}, \mathrm{Al}_{2} \mathrm{O}_{3}$ and $\mathrm{Na}_{2} \mathrm{O}$ (Supplementary figure S10). Similarly, because the crystal crystal matrix contains Ti-magnetite, the gap is also significant in $\mathrm{TiO}_{2}$ and $\mathrm{V}$. Contrarily, there is no Daly gap for Ni because its content is close to zero when the magma reaches the composition of the basaltic andesite. For incompatible elements such as the REE, there is a small gap with a slightly higher content in the dacitic melts because their concentration in the crystals is very low. Using a quantitative approach, Bachmann \& Bergantz (2004) proposed that in a crystal mush where critical cristallinity has been reached, extraction from the crystal mush by upward percolation of a buoyant dacitic melt can be produced by a combination of three mechanisms, compaction if the crystal mush was thick enough (Holness et al., 2017; McKenzie, 2011), micro-settling (melt expulsion resulting from textural adjustments of the grains) and hindered settling (settling in a dense suspension). However, Holness (2018) recently questioned 
the viability of these melt segregation processes. Gas-driven filter pressing and filter pressing can also potentially segregate the melt from the crystal network. Gas-driven filter pressing occurs because of the increasing pressure due to second boiling and the release of this pressure by extraction of the melt from the mush (Sisson \& Bacon, 1999). As shown above, the pressure of volatile saturation can be estimated at about 0.25 to $0.3 \mathrm{GPa}$ suggesting that the magmas were volatile saturated in the main storage region. Gas-driven filter pressing is thus plausible. Filter pressing happens when the magma is squeezed under an external force, possibly resulting from a modification in regional stress. Control by regional stress is possible in the area of La Picada as Cembrano \& Lara (2009) showed that in the NE-SW striking chain of Osorno (and nearby La Picada)-Puntiagudo-Cordon Cenizos, the morphology and spatial distribution of the volcanoes is partly controlled by transpression tectonics that dominates between $34^{\circ}$ to $46^{\circ} \mathrm{S}$ with a major transpressional dextral strike-slip structure, the $1200 \mathrm{~km}$ long Liquiñe-Ofqui Fault zone stretching from $38^{\circ}$ to $47^{\circ} \mathrm{S}$ (Cembrano \& Lara, 2009).

\section{CONCLUSIONS}

Fractional crystallization at low pressure is the dominant process that produced the differentiation from the parent tholeiitic basalts to the dacites at La Picada. We argue that the conspicuous compositional (Daly) gap that separates the most evolved basaltic andesites from the dacites was produced because critical cristallinity was reached at the composition of the most evolved basaltic andesites, preventing eruption of more differentiated lavas. The dacitic interstitial melt produced by differentiation from the basaltic andesites was then segregated from the crystal mush and emplaced 
as dykes that possibly evacuated the dacites as small domes. Moreover, it seems that the basalts and basaltic andesites mainly transported their own crystals. The composition of the recalculated primary magmas indicates last equilibration in the upper mantle and above the dry peridotite solidus suggesting that a component of decompression melting could have taken place. However, because the basalts are enriched in slab components and $\mathrm{H}_{2} \mathrm{O}\left(1.1-2.5\right.$ wt. $\% \mathrm{H}_{2} \mathrm{O}$ in the basalts, about 1-2 wt. $\% \mathrm{H}_{2} \mathrm{O}$ in the calculated primary magmas) compared to N-MORB, wet melting is highly likely. As no trace of high pressure fractionation was detected in mineral composition and whole rock geochemistry, it can be concluded that the basaltic parent magmas differentiated at a depth apparently corresponding to both the site of an intracrustal discontinuity and the level of fluid saturation. There is currently no direct constraint on the depth of differentiation from the primary (12.3 to 13.02 wt. \% MgO) to the parent magmas but as the former are not strictly picritic they could have differentiated in the lower or upper crust. As already pointed out by Hickey-Vargas et al. (2016b), the rapid magma ascent was probably facilitated by the presence of the Liquiñe-Ofqui Fault zone. Insights from La Picada thus stress the potential role of crustal structure on arc magma processes.

\section{ACKNOWLEDGEMENTS}

We are grateful to Luis Lara (SERNAGEOMIN, Chile) for his support in the organization of the field missions. We thank K. Putirka, S. Erdmann and P. Barbey for constructive and thoughtful reviews of an earlier version of this contribution. Additional and insightful comments as well as editorial handling by G. Wörner also contributed to the quality of the paper. 


\section{SUPPLEMENTARY DATA}

Supplementary data for this paper are available at Journal of Petrology online.

\section{FUNDING}

This work was supported by FNRS CDR 19519719 and University of Liège Crédit classique 12/35 to JVDA as well as FNRS and ULiège fieldtrip grants. ON acknowledges support from an Emmy-Noether grant of the DFG (Germany).

\section{REFERENCES}

Adam, J. \& Green, T. (2006). Trace element partitioning between mica- and amphibole-bearing garnet lherzolite and hydrous basanitic melt: 1. Experimental results and the investigation of controls on partitioning behaviour. Contributions to Mineralogy and Petrology 152, 1-17.

Adam, J., Turner, S. \& Rushmer, T. (2016). The genesis of silicic arc magmas in shallow crustal cold zones. Lithos 264, 472-494.

Aigner-Torres, M., Blundy, J., Ulmer, P. \& Pettke, T. (2007). Laser ablation ICPMS study of trace element partitioning between plagioclase and basaltic melts: An experimental approach. Contributions to Mineralogy and Petrology 153, 647-667.

Andújar, J., Scaillet, B., Pichavant, M. \& Druitt, T. (2015). Differentiation conditions of a basaltic magma from santorini, and its bearing on the production of andesite in arc settings. Journal of Petrology 56, 765-794.

Angermann, D., Klotz, J. \& Reigber, C. (1999). Space-geodetic estimation of the Nazca-South America Euler vector. Earth and Planetary Science Letters 171, 329334.

Annen, C., Blundy, J., Leuthold, J. \& Sparks, R. S. J. (2015). Construction and evolution of igneous bodies: Towards an integrated perspective of crustal magmatism. Lithos 230, 206-221.

Annen, C., Blundy, J. \& Sparks, R. S. J. (2006). The genesis of intermediate and silicic magmas in deep crustal hot zones. Journal of Petrology 47, 505-539.

Assumpção, M., Feng, M., Tassara, A. \& Julià, J. (2013). Models of crustal thickness for South America from seismic refraction, receiver functions and surface wave tomography. Tectonophysics $\mathbf{6 0 9}, 82-96$.

Bachmann, O. \& Bergantz, G. W. (2004). On the origin of crystal-poor rhyolites: Extracted from batholithic crystal mushes. Journal of Petrology 45, 1565-1582.

Bachmann, O., Dungan, M. \& Lipman, P. (2002). The Fish Canyon magma body, San Juan volcanic field, Colorado: Rejuvenation and eruption of an upper-crustal batholith. Journal of Petrology 43, 1469-1503. 
Bacon, C. R. \& Druitt, T. H. (1988). Compositional evolution of the zoned calcalkaline magma chamber of Mount Mazama, Crater Lake, Oregon. Contributions to Mineralogy and Petrology 98, 224-256.

Beattie, P. (1994). Systematics and energetics of trace-element partitioning between olivine and silicate melts: Implications for the nature of mineral/melt partitioning. Chemical Geology 117, 57-71.

Bédard, J. (2005). Partitioning coefficients between olivine and silicate melts. Lithos 83, 394-419.

Bédard, J. (2006). Trace element partitioning in plagioclase feldspar. Geochimica et Cosmochimica Acta 70, 3717-3742.

Bédard, J. (2007). Trace element partitioning coefficients between silicate melts and orthopyroxene: Parameterizations of D variations. Chemical Geology 244, 263303.

Bédard, J. H. (2014). Parameterizations of calcic clinopyroxene-melt trace element partition coefficients. Geochemistry, Geophysics, Geosystems 15, 303-336.

Biggs, J., Robertson, E. \& Cashman, K. V. (2016). The lateral extent of volcanic interactions during unrest and eruption. Nature Geoscience 9, 308-312.

Blatter, D., Sisson, T. \& Hankins, W. (2013). Crystallization of oxidized, moderately hydrous arc basalt at mid- to lower-crustal pressures: Implications for andesite genesis. Contributions to Mineralogy and Petrology 166, 861-886.

Blundy, J. \& Wood, B. J. (1991). Crystal-chemical controls on the partitioning of $\mathrm{Sr}$ and $\mathrm{Ba}$ between plagioclase feldspar, silicate melts, and hydrothermal solutions. Geochimica et Cosmochimica Acta 55, 193-209.

Blundy, J. \& Wood, B. J. (2003). Partitioning of trace elements between crystals and melts. Earth and Planetary Science Letters 210, 383-397.

Bouvet De Maisonneuve, C., Dungan, M. A., Bachmann, O. \& Burgisser, A. (2013). Petrological insights into shifts in eruptive styles at volcán Llaima (Chile). Journal of Petrology 54, 393-420.

Brophy, J. (1991). Composition gaps, critical crystallinity, and fractional crystallization in orogenic (calc-alkaline) magmatic systems. Contributions to Mineralogy and Petrology 109, 173-182.

Brown, G. (1956). The layered ultrabasic rocks of rhum, Inner Hebrides. Philosophical Transactions of the Royal Society of London B240, 1-53.

Bunsen, R. (1851). Uner die processe der vulkanischen gesteinsbildungen islands. Ann Phys Chem 83, 197-272.

Carmichael, I. S. (1967). The iron-titanium oxides of salic volcanic rocks and their associated ferromagnesian silicates. Contributions to Mineralogy and Petrology 71, 67-84.

Cashman, K. V. \& Blundy, J. (2013). Petrological cannibalism: The chemical and textural consequences of incremental magma body growth. Contributions to Mineralogy and Petrology 166, 703-729.

Cashman, K. V. \& Blundy, J. D. (2000). Degassing and crystallization of ascending andesite and dacite. Philosophical Transactions A: Mathematical, Physical and Engineering Sciences 358, 1487-1513.

Cembrano, J., Hervé, F. \& Lavenu, A. (1996). The Liquiñe-Ofqui Fault Zone: A longlived intra-arc fault zone in southern Chile. Tectonophysics 259, 55-66.

Cembrano, J. \& Lara, L. (2009). The link between volcanism and tectonics in the southern volcanic zone of the Chilean Andes: A review. Tectonophysics 471, 96113.

Chapman, J., Ducea, M., DeCelles, P. \& Profeta, L. (2015). Tracking changes in 
crustal thickness during orogenic evolution with $\mathrm{Sr} / \mathrm{Y}$ : An example from the North American cordillera. Geology 43, 919-922.

Charlier, B. \& Grove, T. (2012). Experiments on liquid immiscibility along tholeiitic liquid lines of descent. Contributions to Mineralogy and Petrology 164, 27-44.

Chayes, F. (1963). Relative abundance of intermediate members of the oceanic basalttrachyte association. Journal of Geophysical Research 68, 1519-1534.

Chin, E. J., Shimizu, K., Bybee, G. M. \& Erdman, M. E. (2018). On the development of the calc-alkaline and tholeiitic magma series: A deep crustal cumulate perspective. Earth and Planetary Science Letters 482, 277-287.

Cooper, L.B., Ruscitto, D. M., Plank, T., Wallace, P. J., Syracuse, E. M. \& Manning, C. E. (2012). Global variations in h2o/ce:1. Slab surface temperatures beneath volcanic arc. Geochemistry, Geophysics, Geosystems 13.

Costa, F., Scaillet, B. \& Pichavant, M. (2004). Petrological and experimental constraints on the pre-eruption conditions of Holocene dacite from volcan San Pedro. Journal of Petrology 45, 855-881.

Daly, R. (1914). Igneous rocks and their origin. New York: McGraw Hill.

Davidson, J., Morgan, D., Charlier, B., Harlou, R. \& Hora, J. (2007). Tracing magmatic processes and timescales through mineral-scale isotopic data. Annual Reviews of Earth and Planetary Sciences 35, 273-311.

Deruelle, B., Harmon, R. \& Moorbath, S. (1983). Combined Sr-O isotope relationships and petrogenesis of Andean volcanics of South America. Nature 302, 814-816.

Dostal, J., Dupuy, C., Carron, J. P., Dekerneizon, M. L. \& Maury, R. C. (1983). Partition coefficients of trace elements-application to volcanic rocks of St-Vincent, West-Indies. Geochimica et Cosmochimica Acta 47, 525-533.

Draper, D. \& Johnston, A. (1992). Anhydrous PT phase relations of an aleutian high$\mathrm{MgO}$ basalt: an investigation of the role of olivine-liquid reaction in the generation of arc high-alumina basalts. Contributions to Mineralogy and Petrology 112, 501519.

Dungan, M. \& Davidson, J. (2004). Partial assimilative recycling of the mafic plutonic roots of arc volcanoes: An example from the Chilean Andes. Geology 32, 773-776.

Dunn, T. \& Sen, C. (1994). Mineral/matrix partition-coefficients for orthopyroxene, plagioclase and olivine in basaltic to andesitic systems - a combined analytical and experimental study. Geochimica et Cosmochimica Acta 58, 717-733.

Elliott, T. (2003). Tracers of the slab. In: Eiler, J. (ed.) Inside the subduction factory. Washington DC, USA: American Geophysical Union, 23-45.

Erdmann, S., Martel, C., Pichavant, M., Bourdier, J.-L., Champallier, R., Komorowski, J.-C. \& Cholik, N. (2016). Constraints from phase equilibrium experiments on pre-eruptive storage conditions in mixed magma systems: A case study on crystal-rich basaltic andesites from Mount Merapi, Indonesia. Journal of Petrology 57, 535-560.

Ewart, A. \& Griffin, W. (1994). Application of proton-microprobe data to traceelement partitioning in volcanic rocks. Chemical Geology 117, 251-284.

Farner, M. \& Lee, C.-T. A. (2017). Effects of crustal thickness on magmatic differentiation in subduction zone volcanism: A global study. Earth and Planetary Science Letters 470, 96-107.

Fourcade, S. \& Allègre, C. J. (1981). Trace elements behaviour in granite genesis: A case study, the calc-alkaline plutonic association from the Quérigut complex (Pyrénées, France). Contributions to Mineralogy and Petrology 76, 177-195. 
Gaetani, G. A. \& Grove, T. L. (1997). Partitioning of moderately siderophile elements among olivine, silicate melt, and sulfide melt: Constraints on core formation in the Earth and Mars. Geochimica et Cosmochimica Acta 61, 1829-1846.

Gallahan, W. \& Nielsen, R. (1992). The partitioning of Sc, Y, and the Rare Earth elements between high-Ca pyroxene and natural mafic to intermediate lavas at 1 atmosphere. Geochimica et Cosmochimica Acta 56, 2387-2404.

Ghiorso, M. S. \& Gualda, G. (2015). An $\mathrm{H}_{2} \mathrm{O}-\mathrm{CO}_{2}$ mixed fluid saturation model compatible with rhyolite-melts. Contributions to Mineralogy and Petrology 169, 53-82.

Grove, T. L. \& Baker, M. B. (1984). Phase equilibrium controls on the tholeiitic versus calc-alkaline differentiation trends. Journal of Geophysical Research $\mathbf{8 9}$, 3253-3274.

Grove, T. L. \& Donnelly-Nolan, J. M. (1986). The evolution of young silicic lavas at Medicine Lake volcano by fractionation, assimilation and mixing. Contributions to Mineralogy and Petrology 92, 281-302.

Grove, T. L., Elkins-Tanton, L. T., Parman, S. W., Chatterjee, N., Muentener, O. \& Gaetani, G. A. (2003). Fractional crystallization and mantle-melting controls on calc-alkaline differentiation trends. Contributions to Mineralogy and Petrology 145, 515-533.

Grove, T. L., Till, C. B. \& Krawczynski, M. J. (2012). The role of $\mathrm{H}_{2} \mathrm{O}$ in subduction zone magmatism. Annual Review of Earth and Planetary Sciences 40, 413-439.

Gualda, G., Ghiorso, M. S., Lemons, R. \& Carley, T. (2012). Rhyolite-melts: A modified calibration of melts optimized for silica-rich, fluid-bearing magmatic systems. Journal of Petrology 53, 875-890.

Hamada, M. \& Fujii, T. (2008). Experimental constraints on the effects of pressure and $\mathrm{H}_{2} \mathrm{O}$ on the fractional crystallization of high-mg island arc basalt. Contributions to Mineralogy and Petrology 155, 767-790.

Hauri, E. H., Wagner, T. P. \& Grove, T. L. (1994). Experimental and natural partitioning of $\mathrm{Th}, \mathrm{U}, \mathrm{Pb}$ and other trace elements between garnet, clinopyroxene and basaltic melts. Chemical Geology 117, 149-166.

Hermann, J. \& Spandler, C. J. (2008). Sediment melts at sub-arc depths: An experimental study. Journal of Petrology 49, 717-740.

Hickey, R., Gerlach, D. C. \& Frey, F. A. (1984). Geochemical variations in volcanic rocks from Central-South Chile (33-42 ${ }^{\circ}$ s) In: Harmon, R. \& Barreiro, B. (eds.) Andean magmatism. Chemical and isotopic constraints. Nantwich, United Kingdom (UK): Shiva Publishing Limited, 72-95.

Hickey, R. L., Frey, F. A. \& Gerlach, D. C. (1986). Multiple sources for basaltic arc rocks from the Southern Volcanic Zone of the Andes $\left(34^{\circ}-41^{\circ} \mathrm{s}\right)$ : Trace element and isotopic evidence for contributions from subducting oceanic crust, mantle, and continental crust. Journal of Geophysical Research 91, 5963-5983.

Hickey-Vargas, R., Holbik, S., Tormey, D., Frey, F. A. \& Moreno Roa, H. (2016a). Basaltic rocks from the Andean Southern Volcanic Zone: Insights from the comparison of along-strike and small-scale geochemical variations and their sources. Lithos 258-259, 115-132.

Hickey-Vargas, R., Sun, M. \& Holbik, S. (2016b). Geochemistry of basalts from small eruptive centers near Villarrica stratovolcano, Chile: Evidence forlithospheric mantle components in continental arc magmas. Geochimica et Cosmochimica Acta 185, 358-382.

Higgins, M., Voos, S. \& Vander Auwera, J. (2015). Magmatic processes under Quizapu volcano, Chile, identified from geochemical and textural studies. 
Contributions to Mineralogy and Petrology 170, 51-67.

Hildreth, W. \& Moorbath, S. (1988). Crustal contributions to arc magmatism in the Andes of Central Chile. Contributions to Mineralogy and Petrology 98, 455-489.

Hirschmann, M. (2000). Mantle solidus: Experimental constraints and the effects of peridotite composition. Geochemistry, Geophysics, and Geosystems 1, $2000 \mathrm{GC} 000070$.

Holness, M. (2018). Melt segregation from silicic crystal mushes: A critical appraisal of possible mechanisms and their microstructural record. Contributions to Mineralogy and Petrology 173, 48-64.

Holness, M. B., Vukmanovic, Z. \& Mariani, E. (2017). Assessing the role of compaction in the formation of adcumulates: A microstructural perspective. Journal of Petrology 58, 643-673.

Husson, L., Conrad, C. \& Faccenna, C. (2012). Plate motions, Andean orogeny, and volcanism above the South Atlantic convection cell. Earth and Planetary Science Letters 317-318, 126-135.

Irvine, T. \& Baragar, W. (1971). A guide to chemical classification of common volcanic rocks. Canadian Journal of Earth Sciences 8, 523-548.

Jacques, G., Hoernle, K., Gill, J., Hauff, F., Wehrmann, H., Garbe-Schönberg, D., van den Bogaard, P., Bindeman, I. \& Lara, L. (2013). Across-arc geochemical variations in the Southern Volcanic Zone, Chile (34.5-38.0 $\left.0^{\circ} \mathrm{s}\right)$ : Constraints on mantle wedge and slab input compositions. Geochimica et Cosmochimica Acta 123, 218-243.

Jarrard, R. (1986). Relations among subduction parameters. Reviews of Geophysics 24, 217-284.

Jerram, D. A. \& Martin, V. M. (2008). Understanding crystal populations and their significance through the magma plumbing system. Geological Society Special Publication 304, 133-148.

Kelley, K. A., Plank, T., Grove, T. L., Stolper, E. M., Newman, S. \& Hauri, E. H. (2006). Mantle melting as a function of water content beneath back-arc basins. Journal of Geophysical Research 111, B09208.

Kelley, K. A., Plank, T., Newman, S., Stolper, E. M., Grove, T. L., Parman, S. \& Hauri, E. H. (2010). Mantle melting as a function of water content beneath the Mariana arc. Journal of Petrology 51, 1711-1738.

Kinzler, R., Grove, T. \& Recca, S. (1990). An experimental study on the effect of temperature and composition on the partitioning of nickel between olivine and silicate melt. Geochimica et Cosmochimica Acta 54, 1255-1265.

Kratzmann, D., Carey, S., Scasso, R. \& Naranjo, J.-A. (2010). Role of cryptic amphibole crystallization in magma differentiation at Hudson volcano, Southern Volcanic Zone, Chile. Contributions to Mineralogy and Petrology 159, 237-264.

Lambert, I. \& Wyllie, P. (1972). Melting of gabbro (quartz eclogite) with excess water to 35 kilobars, with geological implications. Journal of Geology 80, 693708.

Laubier, M., Grove, T. L. \& Langmuir, C. (2014). Trace element mineral/melt partitioning for basaltic and basaltic andesitic melts: An experimental and laser icp-ms study with application to the oxidation state of mantle source regions. Earth and Planetary Science Letters 392, 265-278.

Lee, C.-T. A., Luffi, P., Plank, T., Dalton, H. \& Leeman, W. (2009). Constraints on the depths and temperatures of basaltic magma generation on earth and other terrestrial planets using new thermobarometers for mafic magmas. Earth and Planetary Science Letters 279, 20-33. 
Lemarchand, F., Benoit, V. \& Calais, G. (1987). Trace element distribution coefficients in alkaline series. Geochimica et Cosmochimica Acta 51, 1071-1081.

Lopez-Escobar, L. (1984). Petrology and chemistry of volcanic rocks of the Southern Andes. In: Harmon, R. \& Barreiro, B. (eds.) Andean magmatism. Chemical and isotopic constraints. Nantwich, United Kingdom (UK): Shiva Publishing Limited.

Lopez-Escobar, L. \& Moreno, R. (1994). Geochemical characteristics of the Southern Andes basaltic volcanism associated with the Liquiñe-Ofqui Fault Zone between 39 degrees and 46 degrees S, Chile. Actas Congreso Geologico Chileno 7, 13881393.

Lopez-Escobar, L., Parada, M., Hickey-Vargas, R., Frey, F., Kempton, P. \& Moreno, H. (1995). Cabulco volcano and minor eruptive centers distributed along the Liquine-Ofqui Fault Zone, Chile $\left(41^{\circ}-42^{\circ} \mathrm{s}\right)$ : Contrasting origin of andesitic and basaltic magma in the Southern Volcanic Zone of the Andes. Contributions to Mineralogy and Petrology 119, 345-361.

Lopez-Escobar, L., Vergara, M. \& Frey, F. A. (1981). Petrology and geochemistry of lavas from Antuco volcano, a basaltic volcano of the Southern Andes ( $\left.37^{\circ} 25^{\prime} \mathrm{s}\right)$. Journal of Volcanology and Geothermal Research 11, 329-352.

Lucassen, F., Wiedicke, M. \& Franz, G. (2010). Complete recycling of a magmatic arc: Evidence from chemical and isotopic composition of quaternary trench sediments in Chile $\left(36^{\circ}-40^{\circ}\right.$ s). International Journal of Earth Sciences 99, 687701.

Luhr, J. \& Carmicahel, I. (1980). The Colima volcanic complex, Mexico. I: Postcaldera andesites from volcan Colima. Contributions to Mineralogy and Petrology 71, 343-372.

Mandler, B. E., Donnelly-Nolan, J. M. \& Grove, T. L. (2014). Straddling the tholeiitic/calc-alkaline transition: The effects of modest amounts of water on magmatic differentiation at Newberry volcano, Oregon. Contributions to Mineralogy and Petrology 168, 1-25.

Marsh, B. (1981). On the crystallinity, probability of occurrence, and rheology of lava and magma. Contributions to Mineralogy and Petrology 78, 85-98.

McDougall, I. \& Harrison, T. (1999). Geochronology and thermochronology by the ${ }^{40} \mathrm{Ar}{ }^{\beta 9} \mathrm{Ar}$ method: Oxford University Press.

McKenzie, D. (2011). Compaction and crystallization in magma chambers: Towards a model of the Skaergaard intrusion. Journal of Petrology 52, 905-930.

Melekhova, E., Annen, C. \& Blundy, J. (2013). Compositional gaps in igneous rock suites controlled by magma system heat and water content. Nature Geoscience $\mathbf{6}$, 385-390.

Montalbano, S., Namur, O., Schiano, P., Bolle, O. \& Vander Auwera, J. (2017). Magma storage conditions and processes at Calbuco volcano (Central Southern Volcanic Zone, Chili). Goldschmidt conference. Paris.

Moreno, H., Lara, L. \& Orozco, G. (2010). Geologia del volcan Osorno, region de Los Lagos. In: Mineria, S. N. d. G. y. (ed.) Carta Geologica de Chile. Santiago.

Morris, J., Leeman, W. \& Tera, F. (1990). The subducted component in island arc lavas; constraints from B-Be isotopes and be systematics. Nature 344, 31-36.

Morse, S. A. (1979). Kiglapait geochemistry ii: Petrography. Journal of Petrology 20, 591-624.

Müntener, O., Kelemen, P. \& Grove, T. (2001). The role of $\mathrm{H}_{2} \mathrm{O}$ during crystallization of primitive arc magmas under uppermost mantle conditions and genesis of igneous pyroxenites: An experimental study. Contributions to Mineralogy and Petrology 141, 643-658. 
Namur, O., Charlier, B., Toplis, M. J., Higgins, M. D., Hounsell, V., Liégeois, J. P. \& Vander Auwera, J. (2011). Differentiation of tholeiitic basalt to A - type granite in the Sept Iles layered intrusion, Canada. Journal of Petrology 52, 487-539.

Namur, O., Humphreys, M. C. S. \& Holness, M. B. (2014). Crystallization of interstitial liquid and latent heat buffering in solidifying gabbros: Skaergaard intrusion, Greenland. Journal of Petrology 55, 1389-1427.

Nandedkar, R., Ulmer, P. \& Müntener, O. (2014). Fractional crystallization of primitive, hydrous arc magmas: An experimental study at $0.7 \mathrm{GPa}$. Contributions to Mineralogy and Petrology 167, 1015-1041.

Navez, J. (1995). Détermination d'éléments en traces dans les roches silicatées par ICP-MS. Tervuren, Belgique: Musée Royal de l'Afrique centrale, 139-147.

Neave, D. \& Putirka, K. D. (2017). A new clinopyroxene-liquid barometer, and implications for magma storage pressures under icelandic rift zones. American Mineralogist 102, 777-794.

Neave, D. A., Maclennan, J., Hartley, M., Edmonds, M. \& Thordarson, T. (2014). Crystal storage and transfer in basaltic systems: The Skuggafjöll eruption, Iceland. Journal of Petrology 55, 2311-2346.

Newman, S. \& Lowenstern, J. (2002). Volatilecalc: A silicate melt- $\mathrm{H}_{2} \mathrm{O}-\mathrm{CO}_{2}$ solution model written in visual basic for Excel. Computers and Geosciences 28, 597-604.

Norman, M., Garcia, M. \& Pietruszka, A. (2005). Trace-element distribution coefficients for pyroxenes, plagioclase, and olivine in evolved tholeiites from the 1955 eruption of Kilauea volcano, Hawaii, and petrogenesis of differentiated riftzone lavas. American Mineralogist 90, 888-899.

Pearce, J. \& Peate, D. (1995). Tectonic implications of the composition of volcanic arc magmas. Annual Reviews of Earth and Planetary Sciences 23, 251-285.

Peccerillo, A. \& Taylor, S. R. (1976). Geochemistry of eocene calc-alkaline volcanic rocks from the Kastamonu area, northern Turkey. Contributions to Mineralogy and Petrology 58, 63-81.

Philpotts, A., Shi, J. \& Brustman, C. (1998). Role of plagioclase crystal chains in the differentiation of partly crystallized basaltic magma. Nature 395, 343-346.

Plank, T. (2014). The chemical composition of subducting sediments. In: Rudnick, R. (ed.) Treatise on geochemistry 2nd edition: Elsevier, 607-629.

Plank, T., Cooper, L. \& Manning, C. (2009). Emerging geothermometers for estimating slab surface temperatures. Nature Geoscience 2, 611.

Plank, T., Kelley, K., Zimmer, M., Hauri, E. \& Wallace, P. J. (2013). Why do mafic arc magmas contain $\approx 4 \mathrm{wt} \%$ water on average ? Earth and Planetary Science Letters 364, 168-179.

Plank, T. \& Langmuir, C. H. (1988). An evaluation of the global variations in the major element chemistry of arc basalts. Earth and Planetary Science Letters $\mathbf{9 0}$, 349-370.

Porter, S. (1981). Pleistocene glaciation in the Southern Lake district of Chile. Quaternary Research 16, 263-292.

Portnyagin, M., Hoernle, K., Plechov, P., Mironov, N. \& Khubunaya, S. (2007). Constraints on mantle melting and composition and nature of slab components in volcanic arcs from volatiles $\left(\mathrm{H}_{2} \mathrm{O}, \mathrm{S}, \mathrm{Cl}, \mathrm{F}\right)$ and trace elements in melt inclusions from the Kamchatka arc. Earth and Planetary Science Letters 255, 53-69.

Putirka, K. D. (2008). Thermometers and barometers for volcanic systems. In: Putirka, K. D. \& Tepley, F. I. (eds.) Minerals, inclusions and volcanic processes. Virginia, USA: The Mineralogical Society of America, 61-120.

Putirka, K. D. (2017). Down the crater: Where magmas are stored and why they erupt. 
Elements 13, 11-16.

Renne, P., Mundi, R., Balco, G., Min, K. \& Ludwig, K. (2010). Joint determination of ${ }^{40} \mathrm{~K}$ decay constant and ${ }^{40} \mathrm{Ar} * / 40 \mathrm{Ar}$ for the Fish Canyon sanidine standard, and improved accuracy for ${ }^{40} \mathrm{Ar} /{ }^{39} \mathrm{Ar}$ geochronology. Geochimica et Cosmochimica Acta 74, 5349-5367.

Reubi, O. \& Blundy, J. (2009). A dearth of intermediate melts at subduction zone volcanoes and the petrogenesis of arc andesites. Nature 378, 571-578.

Reubi, O., Bourdon, B., Dungan, M. A., Koornneef, J. M., Sellés, D., Langmuir, C. H. $\&$ Aciego, S. (2011). Assimilation of the plutonic roots of the Andean arc controls variations in U-series disequilibria at volcan Llaima, chile. Earth and Planetary Science Letters 303, 37-47.

Roeder, P. L. \& Emslie, R. F. (1970). Olivine-liquid equilibrium. Contributions to Mineralogy and Petrology 19, 275-289.

Ruprecht, E. H., Bergantz, G. W., Cooper, K. \& Hildreth, W. (2012). The crustal magma storage system of volcan Quizapu, Chile, and the effects of magma mixing on magma diversity. Journal of Petrology 53, 801-840.

Ruth, D. C. S., Cottrell, E., Cortés, J. A., Kelley, K. A. \& Calder, E. S. (2016). From passive degassing to violent strombolian eruption: The case of the 2008 eruption of Llaima volcano, Chile. Journal of Petrology 57, 1833-1864.

Salters, V. \& Stracke, A. (2004). Composition of the depleted mantle. Geochemistry, Geophysics, and Geosystems Q05B07.

Searle, M., Khan, M., Fraser, J., Gough, S. \& Jan, M. (1999). The tectonic evolution of the Kohistan-Karakoram collision belt along the Karakoram highway transect, North Pakistan. Tectonics 18, 929-949.

Sellés, D. \& Moreno, H. (2011). Geologia del volcan Calbuco. In: Chile, S. N. d. G. y. M.-. (ed.) Geologia Basica No 130.

Sigmarsson, O., Chmeleff, J., Morris, J. \& Lopez-Escobar, L. (2002). Origin of ${ }^{226}$ Ra${ }^{230} \mathrm{Th}$ disequilibria in arc lavas from Southern Chile and implications for magma transfer time. Earth and Planetary Science Letters 196, 189-196.

Sisson, T., Ratajeski, K., Hankins, W. \& Glazner, A. (2005). Voluminous granitic magmas from common basaltic sources. Contributions to Mineralogy and Petrology 148, 635-661.

Sisson, T. W. \& Bacon, C. R. (1999). Gas-driven filter pressing in magmas. Geology 27, 613-616.

Sisson, T. W. \& Grove, T. L. (1993). Experimental investigations of the role of $\mathrm{H}_{2} \mathrm{O}$ in calc-alkaline differentiation and subduction zone magmatism. Contributions to Mineralogy and Petrology 113, 143-166.

Stern, C. (2004). Active Andean volcanism: Its geologic and tectonic setting. Revista Geologica de Chile 31, 161-206.

Stern, C., Futa, K., Muehlenbachs, K., Dobbs, F., Muñoz, J., Godoy, E. \& Charrier, R. (1984). $\mathrm{Sr}, \mathrm{Nd}, \mathrm{Pb}$ and $\mathrm{O}$ isotope composition of late cenozoic volcanics, northernmost SVZ (33-34º). In: Harmon, R. \& Barreiro, B. (eds.) Andeam magmatism. Chemical and isotopic constraints. Nantwich, United Kingdom (UK): Shiva Publishing Limited, 96-105.

Sun, S. \& McDonough, W. (1989). Chemical and isotopic systematics of oceanic basalts: Implications for mantle composition and processes. In: Saunders, A. \& Norry, M. (eds.) Magmatism in the ocean basins: Blackwell Scientific publications, 313-345.

Syracuse, E. M. \& Abers, G. A. (2006). Global compilation of variations in slab depth beneath arc volcanoes and implications. Geochemistry, Geophysics, Geosystems 7. 
Syracuse, E. M., Van Keken, P. \& Abers, G. (2010). The global range of subduction zones thermal models. Physics of the Earth and Planetary Interiors 183, 73-90.

Tassara, A. \& Echaurren, A. (2012). Anatomy of the Andean subduction zone; three dimensional density model upgraded and compared against global-scale models. . Geophysical Journal International 189, 161-168.

Tassara, A., Götze, H.-J., Schmidt, S. \& Hackney, R. (2006). Three-dimensional density model of the Nazca plate and the Andean continental margin. Journal of Geophysical Research 111, B09404.

Toplis, M. \& Carroll, M. (1995). An experimental study of the influence of oxygen fugacity on Fe-Ti oxide stability, phase relations, and mineral-melt equilibria in ferro-basaltic systems. Journal of Petrology 36, 1137-1170.

Toplis, M. \& Corgne, A. (2002). An experimental study of element partitioning between magnetite, clinopyroxene and iron-bearing silicate liquids with particular emphasis on vanadium. Contributions to Mineralogy and Petrology 144, 22-37.

Tormey, D., Hickey-Vargas, R., Frey, F. A. \& Lopez-Escobar, L. (1991). Recent lavas from the Andean volcanic front (33-42 degrees S); interpretations of alongarc compositional variations. Special Paper - Geological Society of America 265, 57-77.

Turner, S., Langmuir, C., Katz, R., Dungan, M. \& Escrig, S. (2016). Parental arc magma compositions dominantly controlled by mantle-wedge thermal structure. Nature 9, 772-776.

Turner, S. J. \& Langmuir, C. H. (2015a). The global chemical systematics of arc front stratovolcanoes: Evaluating the role of crustal processes. Earth and Planetary Science Letters 422, 182-193.

Turner, S. J. \& Langmuir, C. H. (2015b). What processes control the chemical compositions of arc front stratovolcanoes? Geochemistry, Geophysics, Geosystems 16.

Vigneresse, J.-L., Barbey, P. \& Cuney, M. (1996). Rheological transitions during partial melting and crystallization with application to felsic magma segregation and transfer. Journal of Petrology 37, 1579-1600.

Wada, I. \& Wang, K. (2009). Common depth of slab-mantle decoupling: Reconciling diversity and uniformity of subduction zones. Geochemistry, Geophysics, and Geosystems 10, Q10009.

Waters, L. \& Lange, R. (2015). An updated calibration of the plagioclase-liquid hygrometer-thermometer applicable to basalts through rhyolites. American Mineralogist 100, 2172-2184.

Watt, S. F. L., Pyle, D. M., Mather, T. A. \& Naranjo, J. A. (2013). Arc magma compositions controlled by linked thermal and chemical gradients above the subducting slab. Geophysical Research Letters 40, 2550-2556.

Wood, B. J. \& Blundy, J. (1997). A predictive model for rare earth element partitioning between clinopyroxene and anhydrous silicate melt. Contributions to Mineralogy and Petrology 129, 166-181.

Wörner, G., Mamani, M. \& Blume-Oeste, M. (2018). Magmatism in the central Andes. Elements 14, 237-244.

Yoder, H. (1976). Generation of basaltic magma. Washington DC, USA. 


\section{FIGURE CAPTIONS}

Fig. 1: Location of the La Picada volcano. (a) Global multi-resolution topography (GMRT) map of the Andean Southern Volcanic Zone (SVZ) showing the position of La Picada (Pic), merging with that of Osorno (Os), among the chain of active volcanoes. Also shown are the Palena (P), Minchinmavida (M), Apagado (Ap), Hornopiren (H), Calbuco (CL) and Puntiagudo-Cordon Cenizos (Pu) volcanoes. Cordon-Cenizos is a chain of scoria cones and stratovolcanoes extending to the NE of Puntiagudo. Volcanoes discussed in this study are shown with red trinagles, others with yellow triangles. NSVZ, TSVZ, CSVZ and SSVZ designate the different segments of the SVZ, respectively the Northern, Transitional, Central and Southern SVZ (after Hickey-Vargas et al., 2016b; Lopez-Escobar et al., 1995). LOFZ is the Liquiñe Ofqui Fault Zone (after Cembrano \& Lara, 2009). The Juan Fernandez Ridge (JFR) and Chile Rise (CR) are also displayed. The inset map shows subdivision of the Andean arc into a North, a Central, a Southern and an Austral Volcanic Zone (NVZ, CVZ, SVZ and AVZ, respectively). Maps constructed using GeoMapApp. (b) Photograph, taken to the northeast, showing the position of La Picada (Pic) close to the northern flank of Osorno (Os), with Puntiagudo $(\mathrm{Pu})$ in the background. (c) Google Earth image displaying the Osorno-La Picada-Puntiagudo small chain oblique to the main volcanic arc and oriented at $\mathrm{N} 45^{\circ} \mathrm{E}$.

Fig. 2: Photograph of a composite dyke from the southern flank of La Picada (hammer for scale). The inner body (dyke 2) and outer portions (dyke 1) result from dyke-in-dyke intrusion. 
Fig. 3: Geochemical classification diagrams. (a) TAS diagram (dashed line is the limit of Irvine \& Baragar (1971) between alkaline and subalkaline fields). (b) AFM diagram with the limit of Irvine \& Baragar (1971) between tholeiitic and calc-alkaline fields. (c) $\mathrm{SiO}_{2}$ versus $\mathrm{K}_{2} \mathrm{O}$ diagram (limits between fields from Peccerillo \& Taylor (1976)). See major elements section for the definition of High-, Low-, Int-MgO. Analyses recalculated to $100 \%$ on a volatile free basis with total $\mathrm{Fe}$ as $\mathrm{FeO}_{\mathrm{t}}$.

Fig. 4: Photomicrographs of selected samples, taken in transmitted light. (a) Olivine macrocrysts in basalt PIC04 (crossed nicols). (b) Zoned plagioclase macrocrysts in basaltic andesite PIC13 (note the abundance of inclusions) (parallel nicols). (c) Orthopyroxene corona around olivine macrocryst in basaltic andesite PIC33 (parallel nicols). (d) Sparse population of plagioclase macrocrysts in the PIC52 dacite (note the low abundance of inclusions, the slight zoning and the shape-preferred orientation) (crossed nicols).

Fig. 5: (a) Summary of macrocryst compositions in the basalts, basaltic andesites and dacites determined by electron probe microanalysis. $\% \mathrm{An}=\mathrm{Ca}^{*} 100 /(\mathrm{Ca}+\mathrm{Na})$ in moles of cation, $\mathrm{Mg} \#=100 * \mathrm{Mg} /(\mathrm{Fe}+\mathrm{Mg})$ in moles of cation and with $\mathrm{Fe}=$ total $\mathrm{Fe}, \mathrm{n}$ = number of analyses. (b) Pyroxenes Mg\# in the basalts, basaltic andesites and dacites. Mean gives the average $\mathrm{Mg} \#$ on the number $\mathrm{n}$ of analyses.

Fig. 6 : Plagioclase grain from PIC31 showing a typical compositional profile from core to rim. $\% \mathrm{An}=\mathrm{Ca} * 100 /(\mathrm{Ca}+\mathrm{Na})$ in moles of cation. 
Fig. 7: Rhodes diagrams plotting the $\mathrm{Mg} \#$ of the whole rock (WR) versus the $\mathrm{Mg} \#$ of olivine (a) and augite (b). Curves were calculated with a $K_{D}^{F e-M g}$ of 0.3 for olivine (Roeder \& Emslie, 1970) and 0.27 for augite (Putirka, 2008). Microprobe profiles displaying a clear compositional difference between the core and the rim were selected. Indeed, a profile with a nearly constant composition could represent only one zone of a zoned crystal because of a cutting effect. The central black curve was calculated with the equilibrium $K_{D}^{F e-M g}$ and the light grey curves were calculated with error bounds of 0.03 for $K_{D}^{F e-M g} . \mathrm{FeO}_{\mathrm{t}}$ was used in the calculations.

Fig. 8: Harker diagrams showing the major element composition of the La Picada lavas and dykes as well as the Osorno (Moreno et al. (2010) and unpublished data) and Calbuco dacites (Sellés \& Moreno, 2011). Inset in the MgO diagram displays the position of the Moreno et al. (2010) samples (L) and the Ar-Ar ages in ky (Moreno et al. (2010) and this study). Analyses recalculated to $100 \%$ on a volatile free basis with total $\mathrm{Fe}$ as $\mathrm{FeO}_{\mathrm{t}}$.

Fig. 9: Harker diagrams showing the trace element composition of the La Picada lavas and dykes, the Minor Eruptive Centers (MEC : Lopez Escobar et al., 1995) and the Osorno (Moreno et al. (2010) and unpublished data) and Calbuco dacites (Sellés \& Moreno, 2011). Same symbols as in Fig. 8 (MEC = yellow stars).

Fig. 10: REE patterns (left panel) normalized to chondrite $C 1$ of Sun \& McDonough (1989) and spiderdiagrams (right panel) normalized to N-MORB of Sun \& McDonough (1989) of the La Picada lavas and dykes. Same symbols as in Fig.8 except for the dacites. 
Fig. 11 : Trace element composition of the La Picada lavas: comparision with selected occurrences. (a) Nb/Yb vs. Th/Yb diagram of Pearce \& Peate (1995). (b) $\mathrm{La} / \mathrm{Sm}(\mathrm{N}=$ normalized to $\mathrm{C} 1$ chondrite of Sun $\&$ McDonough (1989)) vs. $\mathrm{Ba} / \mathrm{Th}$ diagram of Elliott (2003). The light grey field is the composition of island arcs basalts from Elliott (2003) and the dark grey field is the composition of the South Atlantic MORB. (c) $(\mathrm{La} / \mathrm{Nb})_{\mathrm{N}}$ vs. $(\mathrm{Ba} / \mathrm{Nb})_{\mathrm{N}} .(\mathrm{d})(\mathrm{La} / \mathrm{Yb})_{\mathrm{N}} \mathrm{vs} .(\mathrm{Sr} / \mathrm{Nb})_{\mathrm{N}} \cdot(\mathrm{e})(\mathrm{Nb} / \mathrm{U})_{\mathrm{N}}$ vs. $(\mathrm{Ce} / \mathrm{Pb})_{\mathrm{N}}$. (f) Spiderdiagrams normalized to N-MORB of Sun \& McDonough (1989) (note that the comparison concerns here only the composition of the basaltic parent magmas).

Fig. 12: Age spectra and isochrons showing Ar/Ar experimental results for samples PIC04 (a), PIC06 (b), PIC07 (c), PIC09 (d), PIC12 (e). Data are given in Table 2.

Fig. 13: Frequency distributions of pressure (GPa) estimated with the Neave \& Putirka (2017) clinopyroxene-melt geobarometer for the Int- $\mathrm{MgO}^{+}$and Int-MgObasaltic andesites $(\mathrm{n}=$ number of analyses $)$.

Fig. 14: Compositions of the La Picada whole-rock samples in the pseudoternary projection Olivine (Oliv)-Plagioclase (Plag)-Quartz (Qtz) projected from Clinopyroxene. Only the upper half of the triangle is shown (from 50\% Oliv-50\% Qtz to $100 \%$ Plag). The phase boundaries are those experimentally constrained by Grove et al. (2003) at $0.2 \mathrm{GPa}$ and $\mathrm{NNO}$ on primitive arc magmas from the Cascades. Arrows indicate liquid evolution with decreasing temperature. 
Fig. 15: Relative proportions of macrocrysts and matrix (a) and of macrocrysts (b) in the basalts and basaltic andesites as obtained from point counting. The two lines joining the « Matrix » corner with the $\mathrm{Ol}+\mathrm{Cpx}+\mathrm{Opx}+\mathrm{Ox}-$ Plagio segment in (a) indicate a slightly higher proportion of plagioclase in the Low-MgO samples.

Fig. 16: Comparison of the La Picada trends with the experimental melts of Draper \& Johnston (1992), Blatter et al. (2013) and Andújar et al. (2015) and with the simulations of Rhyolite-MELTS v.1.2.0 (Ghiorso \& Gualda, 2015; Gualda et al., 2012) for the basalt PIC50. Analyses recalculated to $100 \%$ on a volatile free basis with total $\mathrm{Fe}$ as $\mathrm{FeO}_{\mathrm{t}}$.

Fig. 17: Estimation of the mantle melting conditions. (a) Pressure and temperature of last equilibration derived with the Lee et al. (2009) geothermobarometer for the recalculated primary magmas (same symbols as in Fig. 15) and compared with the dry peridotite solidus of Hirschmann (2000). Errors bars as given by Lee et al. (2009). Results from Watt et al. (2013) are shown for comparison (see Fig. 1 for the location of Apagado, Hornopiren, Palena an Minchinmavida volcanic centers). (b) Melt fraction $(\mathrm{F})$ vs. calculated $\mathrm{H}_{2} \mathrm{O}$ concentration (in wt. \%) in the mantle source $\left(\mathrm{C}_{\mathrm{H} 2 \mathrm{O}}\right)$ following (Kelley et al., 2010) for high (calculated from $\mathrm{TiO}_{2} / \mathrm{Y}$ ) and low $\mathrm{TiO}_{2}$ (constant 0.133 wt. \%) contents in the mantle source. The calculated hydrous melting relationships for the different primary magmas are shown as solid curves.

Fig. 18: Schematic sketch of the subduction geometry beneath La Picada illustrating the estimated depth of last equilibration of the primary magma and the location of the main magma storage region. Depth of the intracrustal discontinuity (ICD) separating 
the upper and lower continental crust from Tassara et al. (2006), MOHO depth, volcano-trench distance and volcano-slab distance from Syracuse \& Abers (2006) (data for Osorno), schematic mantle isotherms (blue dotted lines) from Wada \& Wang (2009). Question marks indicate the possible location of differentiation from the primary magmas to the basaltic parent magmas close to the MOHO. Scale of the volcano is exaggerated for graphic purpose.

Fig. 19: Test of mixing process, following the method of Fourcade \& Allègre (1981). $\mathrm{C}_{\mathrm{b}}, \mathrm{C}_{\mathrm{a}}, \mathrm{C}_{\mathrm{int}}$ are the concentrations in the mafic, felsic and mixed components. The hypothetical proportion of the mafic end-member $(\mathrm{x})$ in the mixing process is given by the slope of the regression line. (a-b) PIC43, PIC44 and PIC13 are respectively the mafic, acid and intermediate facies. (c-d) PIC04, PIC51 and PIC34 are respectively the mafic, acid and intermediate facies.

Fig. 20: Test of fractional crystallization process in diagrams with two incompatible elements (a) Rb vs. Ta and (b) Ta vs. Th and in bilogarithmic diagrams (c) Log (Rb) vs. $\log (\mathrm{Ni})$ and $(\mathrm{d}) \log (\mathrm{Rb})$ vs. $\log (\mathrm{Y})$ (note that dacites from dykes 2 and samples PIC14-15 are not shown). 
